\title{
Smetana's The Brandenburgers in Bohemia and Czech Nationalism: A Historical Reevaluation
}

\author{
MARTIN NEDBAL
}

\begin{abstract}
Post-WWII studies of Smetana's The Brandenburgers in Bohemia view the work as an expression of the Czechs' resistance to various kinds of national oppression, by the Austrian Empire, and by Austrian and Bohemian Germans. This article shows that these views emerged only long after the opera was written in 1862-3 and premiered in 1866. An exploration of Czech political debates in the early 1860s, contemporaneous historical accounts of the thirteenthcentury events the opera depicts, Smetana's sketches, censorship practices and records, and reviews of The Brandenburgers from the months after the premiere illustrates that the mid-nineteenth-century conceptualization of the Czechs' position within the Austrian Empire and their relationship to Germans and German Bohemians was less oppositional and binary than in later decades. This context in fact clarifies numerous ambiguous aspects of Smetana's opera, such as the main villain's characterization and the ambiguous depiction of the Brandenburgers. A brief survey of the opera's reception history shows, furthermore, that the intensely nationalistic, anti-German, and anti-Austrian perspective on The Brandenburgers, still accepted nowadays, became particularly prominent in reaction to various twentieth-century totalitarian ideologies and were strongly influenced by the opera's first post-WWII production at the former New German Theater in September 1945.
\end{abstract}

On September 4, 1945, a performance of Bedřich Smetana's opera The Brandenburgers in Bohemia inaugurated the first post-WWII season in the building in central Prague that, until a few months earlier, had been commonly referred to as the New German Theater (Neues deutsches Theater). Completed in 1888 in part thanks to donations by Prague's German elites, the building was appropriated by a group of Czech artists during the uprising of Prague's Czechs against the Nazi occupation in early May 1945. In commemoration of the uprising, the building was then renamed as the Fifth of May Theater ("Divadlo pátého května”). Amidst mass deportations of German Bohemians out of Czechoslovakia on the principle of collective guilt for Nazi atrocities, the reopening of the former German Theater acquired a symbolic significance. ${ }^{1}$ As Kelly St. Pierre has pointed out, post-WWII performances of Smetana's works operated "as symbols of endurance ... [and] took place against the violent backdrop of ethnic 'cleansing' ('očista')." The 1945 Brandenburgers emphasized recent events by using an elevated stage in the shape of a swastika that disintegrated at the end of the opera. ${ }^{3}$ The symbolic importance of this particular production was

\footnotetext{
${ }^{1}$ Throughout this article I use the term German Bohemians to refer to those inhabitants of Bohemia who identified as German. "German Bohemian" corresponds to the concept of "Deutschböhme" that often appears in German-Bohemian writings especially throughout the nineteenth century, The nineteenth-century history of the distinction between the adjectives "Bohemian" and "Czech" is explained in Jeremy King, Budweisers into Czechs and Germans: A Local History of Bohemian Politics, 1848-1948 (Princeton, NJ: Princeton University Press, 2002), 24, https://doi.org/10.1515/9780691186382.

${ }^{2}$ Kelly St. Pierre, Bedřich Smetana: Myth, Music, and Propaganda (Rochester, NY: University of Rochester Press, 2017 ), 102.

${ }^{3}$ Tomáš Vrbka, Státní opera Praha: Opera 1888-2003 (Prague: Státní opera, 2004), 253.
} 
recognized by the political leadership of the newly formed Third Czechoslovak Republic; a few days after the premiere performance, on September 18, President Edvard Beneš attended a repeat performance of The Brandenburgers. An essay in the program booklet for the 1945 performances views the opera as reflecting both recent events and a long-term struggle of the Czechs against foreign, predominantly German, oppression. ${ }^{4}$

Assertions that The Brandenburgers, an opera set during the late thirteenth-century occupation of Bohemia by the soldiers of Otto V of Brandenburg, expressed the suffering and eventual triumph of ethnic Czechs at the hands of German oppressors appear in many other post-WWII discussions about Smetana. In his 1948 monograph Smetanovy zpěvohry, lawyer and author Přemysl Pražák combines the opera's post-WWII meanings with what he sees as its original significance-as a work that celebrates the Czech nation's ability to rise against alien oppressors. Pražák imagines that had the opera not been banned during the German Protectorate, it would have easily become a signal for an anti-Nazi revolt, similar to La muette de Portici in Belgium in $1830 .^{5} \mathrm{He}$ also suggests that the opera's creators and original audiences in the 1860s already understood the work in similar ways, and that from the moment of its inception The Brandenburgers "emphasized the revolutionary, always alive and watchful strength of the [Czech] nation." Unlike some of its literary sources, Pražák adds, the libretto, likely at Smetana's suggestion, "shows the triumph of the [Czech] people and stresses their rightful superiority on home soil." Pražák's interpretation resonates with statements about The Brandenburgers in numerous studies by AngloAmerican writers. Smetana biographer Brian Large writes that the opera exudes "ardent nationalism . . at a time when all Bohemians were striving to break from the Hapsburgs and establish an independent national identity." John Tyrrell claims that the subject of The Brandenburgers is "unequivocally nationalist," has been understood as "anti-German and thus anti-Austrian," and that for "Smetana's nineteenth-century Czech contemporaries ... the Austrian Habsburgs were occupying Bohemia" like the Brandenburgers.9 Jan Smaczny writes that "though in a remote time, and with Germans rather than Austrians as the invader, the implications for the Czech subjects of the Habsburg crown would have been clear." ${ }^{10}$ More recently, Richard Taruskin, in his Oxford History of Western Music, has claimed that the opera's opening recitative, decrying the Brandenburger occupation of Bohemia, "could easily be read as pertaining to the nineteenth-century Austrians."11

Such understandings of The Brandenburgers contrast with those studies of Smetana's works that show nineteenth- and twentieth-century conceptualizations of Czech national music as constantly unstable and anything but clear-cut and binary. St. Pierre's discussion of Smetana's "Vyšehrad" and

\footnotetext{
4 "When we project the plot of the opera to the present, we see more than an obvious correspondence with what we have experienced recently.... [The opera's content also prefigures] the modern national and social oppression, intensified by the Germans with the abused tools of civilization.” The booklet is preserved in Prague at the Bedřich Smetana Museum. All translations from Czech and German in this article are mine. The booklet mentions that the premiere performance was introduced by a speech by Zdeněk Nejedlý. It is unclear whether the essay is identical with the speech, because it concludes with the acronym "JMKt."

${ }^{5}$ On the ban, see also Brian Locke, Opera and Ideology in Prague: Polemics and Practice at the National Theater, 1900-1938 (Rochester, NY: University of Rochester Press, 2006), 334, n. 2, and Dějiny české hudebni kultury, 1890-1945, ed. Robert Smetana and Jiř́i Bajer, vol. 2 (Prague: Academia, 1981), 193.

${ }^{6}$ Přemysl Pražák, Smetanozy zpěvohry, vol. 1 (Prague: Vydavatelství za svobodu, 1948), 92.

${ }^{7}$ Pražák, 92.

${ }^{8}$ Brian Large, Smetana (New York: Praeger Publishers, 1970), 146-147.

${ }^{9}$ John Tyrrell, Czech Opera (New York: Cambridge University Press, 1988), 1, 129-130.

${ }_{10}$ Jan Smaczny, "Grand Opera among the Czechs," in The Cambridge Companion to Grand Opera, ed. David Charlton (New

York: Cambridge University Press, 2003), 374, https://doi.org/10.1017/CCOL9780521641180.019.

${ }^{11}$ Richard Taruskin, The Oxford History of Western Music, vol. 3 (New York: Oxford University Press, 2010 ), 448.
} 
Christopher Campo-Bowen's article about The Bartered Bride in 1924 Paris are two recent examples of such approaches. ${ }^{12}$ A closer look at The Brandenburgers's inception and reception history shows that they are likewise fraught with contradictions. Late nineteenth- and early twentieth-century Czech critics and scholars, especially Otakar Hostinský and Zdeněk Nejedlý, operated with these contradictions in reference to Smetana's musical style in The Brandenburgers and in an attempt to defend the opera from accusations of being too Wagnerian. ${ }^{13}$ In 1949, for example, Nejedlý, expanding on Hostinskýs ideas, stressed that although the musical style of The Brandenburgers is infused with the spirit of Germanic opera (especially Weber, Wagner, and Beethoven's Fidelio), it is also uniquely original and inherently Czech. ${ }^{14}$ The following pages focus on how the opera interacted with political, as opposed to aesthetic, ideologies at the time of its creation and first production. I also discuss how in the following decades critical reactions to and stage interpretations of The Brandenburgers resonated with Czech elites' changing attitudes toward German Bohemians and the Habsburg emperors. My exploration shows that in the 1860s the opera's fractured meanings resonated with the complex political and cultural negotiations about Czech society's relationship to the Austrian Empire, whereas more straightforward anti-German and anti-Austrian ideas were imputed (sometimes even literally inserted) into the work only as Czech politics radicalized in the late nineteenth century.

\section{The Ambiguity of The Brandenburgers}

Throughout the opera, patriotic and pro-Czech moments are counterbalanced with others that undermine the view of The Brandenburgers as an expression Czech nationalism. There is certainly a large dose of patriotism in the dramatic episode from thirteenth-century Bohemian history on which the opera is based. In August of 1278, the Bohemian king Přemysl Otakar II was defeated and killed in the Battle on the Marchfeld by the Holy Roman King Rudolf of Habsburg. After the battle, Přemysl's nephew Otto V, Margrave of Brandenburg, became the regent of Bohemia and the guardian of Přemysl's son, the future king Wenceslas II. Otto abducted Wenceslas away from Prague and invited into Bohemia militias from Northern Germany that terrorized the Bohemian population. The terror ended in 1280 when Otto ordered all foreigners not settled in Bohemia to leave the country. The opera combines the abduction of Wenceslas in February 1279 in the first act and the recall of the Brandenburgers away from Bohemia in late 1280 in the second act. The plot focuses on several distinct groups: the Prague burghers led by Volfram Olbramovič; the Prague rabble led by the vagabond Jíra; the Czech villagers represented by an old man; and a group of Brandenburger soldiers led by the captain Varneman. The interactions and conflicts between the four groups form the background for the story of Volfram's daughter Ludiše and two other Prague burghers: Junoš, whom Ludiše loves, and Jan Tausendmark, whom she spurns and who therefore has her and her two sisters abducted by the Brandenburgers.

Throughout the opera, various characters express politically charged ideas that could be connected to the struggle of the Czechs for greater cultural and political recognition within the Habsburg Empire in the

\footnotetext{
${ }^{12}$ St. Pierre, 25-45; Christopher Campo-Bowen, “An Operatic Locarno: The Paris Premier of Smetana's The Bartered Bride and Czechoslovak-French Cultural Diplomacy," Cambridge Opera fournal 28, no. 3 (Fall 2017): 283-312, https://doi.org/10.1017/S0954586716000434.

${ }_{13}$ See Otakar Hostinský, Bedřich Smetana a jeho boj o moderni českou hudbu (Prague: Laichter, 1901), 94-99, 371-383; and Zdeněk Nejedlý, Zpěvohry Smetanovy (Prague: Melantrich, 1949), 42-75.

${ }^{14}$ Nejedlý, 47, 55, 64-65. For a general overview of Hostinskýs ideas, see Locke, 24-28. For a discussion about the debates about Smetana's Wagnerism in The Brandenburgers, see St. Pierre, especially 56-57.
} 
mid-nineteenth century. In the opera's opening scene, for example, one of the Prague burghers twice mentions that the Brandenburgers are suppressing the Czech language. At the beginning of the second act, moreover, a powerful chorus presents the plight of the Czech people in a sympathetic light: "Our beautiful Czech land / They destroyed with brutality / And the famous Czech nation / They enslaved!" 15 The opera also presents Prague's thirteenth-century burghers as ardent Czech patriots, although already mid-nineteenth-century Czech historians were showing that the city's medieval patriciate was predominantly German-speaking. The opera's librettist, Karel Sabina, also makes the historically documented German names sound more Slavic.

Yet the opera does not necessarily present a clear image of a victorious Czech struggle against Germanic oppressors. The opera mostly avoids depictions of the Brandenburgers' rule of terror, as was pointed out already by one reviewer of the premiere performance. ${ }^{16}$ The Brandenburger troops, furthermore, are called away from Bohemia by their master Otto. Even at the very end of the opera, in Act III, Scene 7, the Brandenburger captain does not appear threatened by the Czech characters and announces that he is leaving the country solely at the request of his lord: "If you want our blood / fear for your lives! / We were ordered to leave, / and we will leave tomorrow morning." As a result, the ending of the opera does not so much depict a triumph of the Czech people over their enemy as it expresses their elation after the conclusion of a period of adversity.

Marta Ottlová and Milan Pospíšil note Smetana and Sabina's non-aggressive portrayal of the Brandenburgers as well, and contrast it with French grand operas' depictions of explicit national and religious conflicts; they point out that, unlike Parisian works of Meyerbeer and others, Sabina does not focus on a historical conflict and does not use history to motivate the actions of the characters. ${ }^{17}$ Ottlová and Pospíšil suggest that this difference must be based on Sabina’s "general understanding of history" ("v názoru na historii vůbec"), but they do not specify what that understanding might have been. ${ }^{18}$ Part of the opera's treatment of the Brandenburgers might be related to the fact that in the 1860s, Germans were still not perceived as a unified national group in Bohemia. Mid-nineteenth-century Central Europeans viewed German Bohemians as distinct from the Saxons or the Prussians, as exemplified by the fact that at the beginning of the Austro-Prussian War of 1866, both Czech and German-Bohemian commentators welcomed with sympathy Saxon troops escaping to Bohemia from the advancing Prussian army. ${ }^{19}$ Also, during the 1866 Prussian occupation of Bohemia, the Prussian soldiers looked down upon the Austrian Germans. ${ }^{20}$ This context suggests that around the time of its conception and first performance, Sabina's libretto and the Czech-Brandenburger opposition it depicts could not have been viewed primarily as a representation of a general Czech-German or Czech-Austrian conflict. If anything, this opposition might have been interpreted, particularly in 1866, as specifically anti-Prussian. Antipathy for Prussia among Czechs and German Bohemians in fact dated back at least to the Seven Years' War (1756-1763), in which

\footnotetext{
${ }^{15}$ On Smetana's musical settings of these patriotic statements, see Tyrrell, 6-8.

${ }^{16}$ Politik, January 10, 1866.

${ }^{17}$ Marta Ottlová and Milan Pospíšil, “K problematice české historické opery 19. století,” Hudební rozhledy 34, no. 4 (1981): 171.

${ }^{18}$ Ottlová and Pospíšil, 171.

${ }^{19}$ Michael Borovička, Jiří Kaše, Jan P. Kučera, and Pavel Bělina, Velké dějiny zemí Koruny české, vol. 12a (Prague: Paseka, 2012), 123.

${ }^{20}$ Velké dějiny zemi Koruny české, vol. 12a, 141.
} 
the Prussians invaded Bohemia, and besieged and bombarded Prague. ${ }^{21}$ Smetana himself linked the Brandenburgers to the Prussians, though only long after the 1866 occupation, in a retrospective diary written, according to Olga Mojžíšová, between January 1875 and early $1876 .^{22}$ In the diary, Smetana writes that a few months after the premiere of The Brandenburgers (January 5, 1866) and a few weeks after the premiere of The Bartered Bride (May 30, 1866), the "real Brandenburgers" came to Bohemia ("přit[á]hl[i] skutečn[í] 'Braniboři do Čech'!”). ${ }^{23}$

\section{Bohemians in The Brandenburgers}

The opera also lacks clarity in the national characterization of the principal male Bohemians. Although Tausendmark is distinguished from the other Czech characters, he is not clearly marked as Germanic (or German-Bohemian). In Act I, Scene 2, for example, Junoš accuses Prague burghers with German-sounding names (as opposed to the burghers with Slavicized names introduced in the opera's opening) of assisting in the looting of Prague: "Among the looters, shame, shame! The servants of the Rosts and the Tausendmarks! Yes, Jakob Velflovic, Friedinger and Martin of Cheb were in the lead!" In Act I, Scene 4, moreover, Ludiše mockingly exhorts Tausendmark to join "his friends, the Brandenburgers." Yet, the opera does not present Tausendmark as a complete alien. Particularly significant is the moment in which Varneman, the captain of the Brandenburger soldiers, condemns Tausendmark in Act III, Scene 1: "Not even thousands of foreigners do as much harm to the Czech land as a single villain like you, for whom this is a motherland but who tramples and betrays her constantly." Many contemporaneous commentators criticized Sabina for giving one of the most explicitly nationalist statements of the opera to a Brandenburger. ${ }^{24}$ Through Varneman's denunciation the libretto clearly acknowledges that even the alienated Tausendmark has an undeniable place within the Bohemian community. Moreover, at the very beginning of the opera, the statement "Alas, that there are so many apostates among the Czechs" by the Czech knight Oldřich Rokycanský makes it clear that similar to Tausendmark, many Czechs collaborate with the Brandenburgers. Either during the final rehearsals or soon after the opera's premiere, Smetana increased Tausendmark's ambiguity when he added into Act III, Scene 1, the aria "Tvůj obraz dívko" ("Your image, maiden"-Ex. 1) to accommodate the famous Czech baritone Josef Lev. $^{25}$

\footnotetext{
${ }^{21}$ On Czech attitudes toward Prussia, see Tyrrell, 61 and 129-130, and Mirko Očadlík, Smetanovi Braniboři v Čechách (Prague: Orbis, 1953), 15. On the German-Bohemian attitudes, see Pieter M. Judson, Exclusive Revolutionaries: Liberal Politics, Social Experience, and National Identity in the Austrian Empire, 1848-1914 (Ann Arbor: University of Michigan Press, 1996), 107-108, https://doi.org/10.3998/mpub.15283.

${ }^{22}$ For an extensive discussion of Smetana's diaries and the reasons why they still remain unpublished, see Olga Mojžišová, "Deníky Bedřicha Smetany. Jejich pramenná hodnota a ediční problematika" (Ph.D. diss., Charles University in Prague, 2013); on this particular diary, see pp. 95-98.

23 “Tagebuch / von December 1861 an, durch / 1862," Bedřich Smetana Museum, shelf mark NM-MBS S 217/1099. The diary entry has been published in František Bartoš, Bedřich Smetana: Letters and Reminiscences, trans. Daphne Rusbridge (Prague: Artia, 1955), 103. Bartoš does not contextualize the entry, merely states that it comes from Smetana's Diary, and places it within documents from 1866.

${ }^{24}$ For example, the review in the Old-Czech paper Národ (January 8, 1866), cited in Pražák, 119. At the same time, Sabina is following a convention in other Czech and German-Bohemian plays and operas about foreign invasions. In three earlier works dealing with the Swedish siege of Prague in 1648, by Štěpánek, Škroup, and Tyl, various Swedish characters express disbelief that a Prague citizen could betray his native city.

${ }^{25}$ In the introduction to his critical edition of Sabina's libretto, Nejedlý claims that the aria was added only after the premiere, but it is already discussed in a review in Bohemia on January 10, 1866, five days after the premiere. See Karel Sabina, Braniboři v Čechách, ed. Zdeněk Nejedlý (Prague: Sbor pro postavení památníku Bedřichu Smetanovi, 1918), xviii.
} 


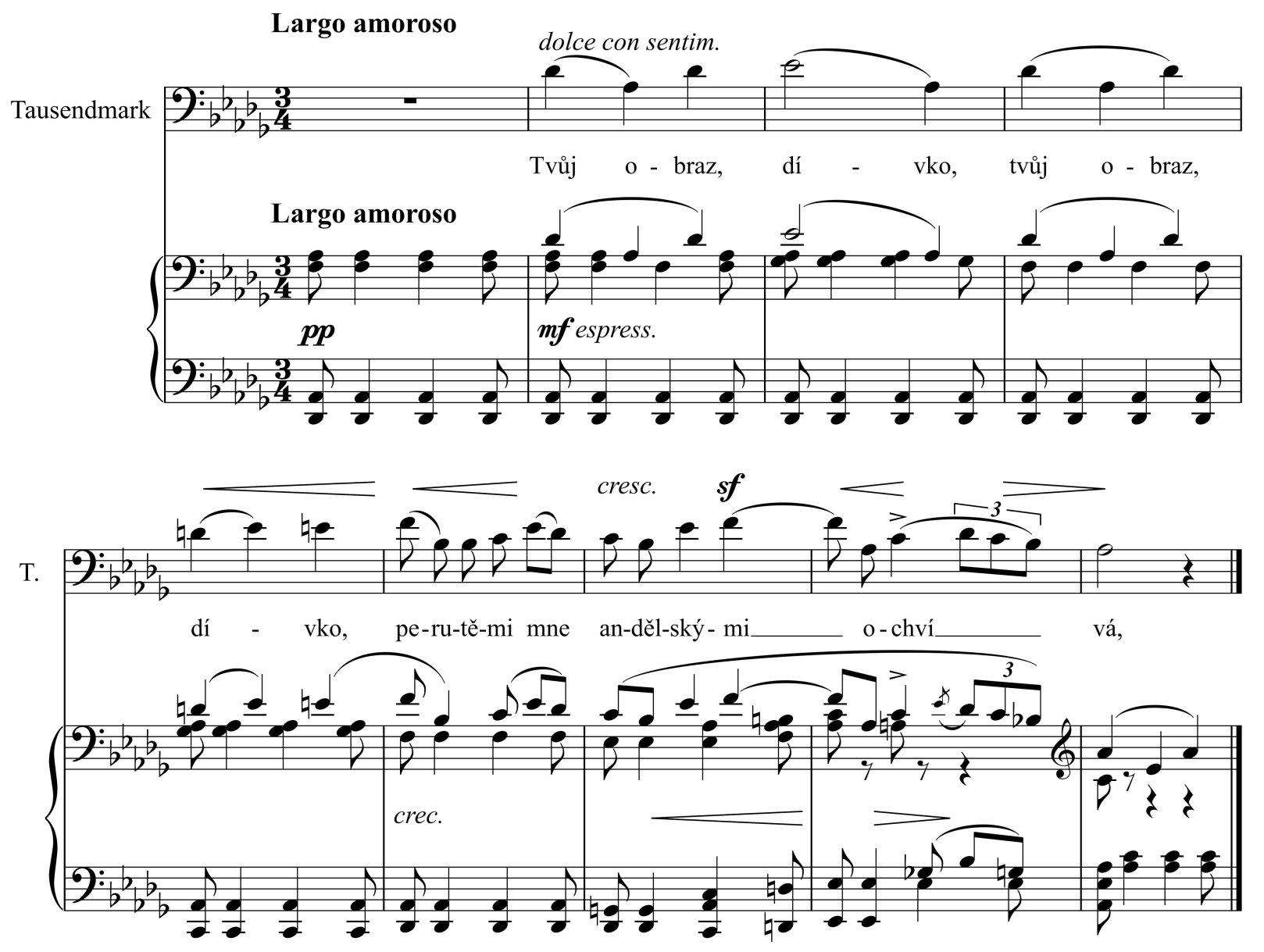

Example 1: Tausendmark's aria "Tvůj obraz dívko" ("Your image, maiden”) in Act III, Scene 1, opening, mm. 177-185. Text: "Tvůj obraz dívko; tvůj obraz dívko, perutěmi mne andělskými ochvívá."

("Your image, maiden; your image, maiden, revives me as if with angelic powers").

The aria and the preceding recitative express earnest feelings for Ludiše and remorse at his evil actions. Smetana's lyrical music sheds a sympathetic light on Tausendmark and transforms him into the most three-dimensional and human character of the opera. ${ }^{26}$

Tausendmark's ambiguous portrayal also stands out in comparison to similar characters in earlier Czech works, which possibly served as models for Sabina's libretto. Josef Lev's presentation of Tausendmark's sympathetic third-act aria brings to mind the Brandenburger knight Adalbert, an honorable German-speaking character from Josef Kajetán Tyl's 1847 novella The Brandenburgers in Bohemia (published in the magazine Pražský posel). Although he belongs to the occupational forces, Tyl's Adalbert is concerned about the plight of the Czech population and starts to fall in love with the main Czech heroine. ${ }^{27}$ As a villain, Tausendmark parallels but also significantly differs from Arnošt Ottowaldský, the apostate in Jan Nepomuk Štěpánek's 1812 play Obležení Prahy od Švejdů, aneb Vẽrnost a udatnost česká (The siege of Prague by Swedes, or Czech faithfulness and bravery), which was revived in

\footnotetext{
${ }^{26}$ The reviewer for the German-Bohemian journal Bohemia picked up on the ambiguity of Tausendmark's third-act aria when he claimed that the piece is musically beautiful but presents the character as too salon-like and weak.

${ }^{27}$ See also Sabina, Braniboři v Čechách, xii.
} 
Prague in $1865 .{ }^{28}$ Similar to The Brandenburgers, Štěpánek's play depicts a foreign invasion to Bohemia, specifically the Swedish siege of Prague in 1648. Ottowaldský betrays a secret weakness in the fortifications of Prague's Lesser Town to the Swedes so that they are able to occupy it and later tries to set the rest of the city on fire. Similar to Tausendmark, Ottowaldský is marked as a national "Other" by his Germanic name and his association with the German-Bohemian city of Eger/Cheb, where he owns an estate. Unlike Tausendmark, however, Ottowaldský expresses his disdain for the Czechs on several occasions, such as in Act III, Scene 6, where he says that his heart is filled with pleasure when he imagines the proud Czechs humiliated and begging for mercy. ${ }^{29}$

The depiction of the Prague patricians is myopic as well. Volfram Olbramovič, for example, is based on the historical figure of Wolfram, a thirteenth-century Prague citizen who, according to nineteenthcentury historian Václav Vladivoj Tomek, led a group of Prague burghers in opposition to Otto of Brandenburg although he was most likely a German speaker, from a family that originated, just like Ottowaldský, in Eger/Cheb. ${ }^{30}$ To deemphasize Wolfram's Germanness, Sabina added the Slavic patronymic "Olbramovič" to his name, and he also renamed his historically documented daughters Christina, Elizabeth, and Katharina as Ludiše, Vlčanka, and Děčana. ${ }^{31}$ Yet, Sabina himself was not consistent in Slavicizing Wolfram's name, and the printed libretto refers to him with either the Germanic "Volfram" or its ultra-Slavicized variant "Olbram"; these sometimes even alternate on the same page. ${ }^{32}$

The confusing nomenclature suggests that for Sabina and Smetana, the distinction between Czechs and German Bohemians was not clearly established yet. As numerous historians of mid-nineteenthcentury Bohemia have noted, nineteenth-century Czech speakers could easily join German-speaking communities, and German Bohemians and Czech speakers who switched to the predominant use of German (such as Smetana himself) were encouraged to identify with Czechness. ${ }^{33}$ The fluid conceptualization of national identity was politicized in the mid-1860s, most prominently in the 1865 treatise "The Idea of the Austrian State" ("Idea státu rakouského") by Czech historian and politician František Palacký, one of the leaders of the Czech National Party in the Bohemian Diet. Palacký published the 1865 treatise together with a new edition of his famous open letter to the Frankfurt Parliament, originally written in April 1848. ${ }^{34}$ In the 1848 letter, Palacký refused the invitation to participate in the Parliament, claiming that as a Czech Slav he preferred to belong to a federalized Austria as opposed to a

\footnotetext{
${ }^{28}$ Discussed in Tyrrell, 130. In 1845, the play was adapted by Josef Pečírka into a libretto for Jan Nepomuk Škroup's opera Švédové v Praze (The Swedes in Prague). Škroup's operatic adaptation of Štěpánek's play was produced in 1867 (this was its first complete production with a libretto adaptation by Emanuel Züngel; only excerpts were performed in 1845). Another play that Czech intellectuals would likely be familiar with during the 1860s, was Tyl's Měštané a študenti, aneb Obležení Prahy od Švédů (Burghers and students, or the siege of Prague by the Swedes), written in 1850 on the basis of Štěpánek's play and performed at the Provisional Theater in 1870.

${ }^{29}$ Diwadlo od F. N. Štěpánka, 68.

${ }^{30}$ Václav Vladivoj Tomek, Dějepis města Prahy, vol. 1 (Prague: Řivnáč, 1855), 297. In the late thirteenth century, Eger/Cheb was in fact a free city within the Holy Roman Empire and was incorporated into the Bohemian Kingdom only in the fourteenth century.

${ }^{31}$ See also Sabina, Braniboři v Čechách, xiii.

32 This happens in the 1874 edition of the libretto, Braniboř v Čechách (Prague: Urbánek, 1874), 4.

${ }^{33}$ The gradual and complex transformation of Bohemians into Czechs and Germans in Prague is described by Gary B. Cohen, The Politics of Ethnic Survival: Germans in Prague, 1861-1914, 2nd rev. ed. (West Lafayette, IN: Purdue University Press, 2006), esp. 66-68. For a musicological case study of a transformation of Eduard Hanslick's transformation from a Bohemian into an Austrian-German, see David Brodbeck, Defining Deutschtum: Political Ideology, German Identity, and Music-Critical Discourse in Liberal Vienna (New York: Oxford University Press, 2014), chapter 1. See also King, 3-6, https://doi.org/10.1093/acprof:oso/9780199362707.001.0001.

${ }^{34}$ For an overview of the two treatises, see Velké dějiny zemí Koruny české, vol. 12a, 96-103. Palacký's essays appeared in František Palacký, Idea státu rakouského (Prague: Kober, 1865).
} 
unified Germany, and he also emphasized the natural rights of ethnic Czechs for self-determination and an autonomous government. ${ }^{35}$ The 1865 treatise, by contrast, focused on historical state rights of the Czech lands within federalized Austria. ${ }^{36}$ Palacký's shift from natural to historical rights was in part a reaction to the resistance German Bohemians raised in the early 1860s to the idea that Bohemia should be considered a natural habitat of a single Slavic ethnic group. The fact that the 1865 publication featured both the 1848 letter focused on Czech-centric natural rights and the 1865 treatise discussing territorially defined historical rights parallels The Brandenburgers's libretto, which both distinguishes between Czechs and German Bohemians and projects a notion of a more or less uniform Bohemian community.

\section{The Brandenburgers and Censorship}

The ambiguity of the opera's plot has raised the question about the role of Austrian censorship in The Brandenburgers's inception. Already in 1953, Mirko Očadlík was surprised that Austrian censors allowed the opera's "revolutionary" content, which he associated with the work's depiction of the protoproletarian struggle between the Prague rabble and the Prague patricians. ${ }^{37}$ Jan Smaczny wondered whether the absence in The Brandenburgers of scenes with "national squabbles" between the Czechs and the Brandenburgers, which would be represented by divided choruses in the style of French grand opera, reflects Austrian censorship's ban on operatic depictions of national conflicts. ${ }^{38}$ These views exemplify a common tendency of later critics to use censorial procedures as a means of imputing unprovable and often anachronistic attitudes to artists from earlier periods. ${ }^{39}$ The idea that Sabina and Smetana self-censored themselves in fear of a potential ban does not correspond to any clear statements by the authors about the political significance of their opera. It is impossible to know whether or not Smetana and Sabina initially conceived of the story as a symbol of social injustice or a national conflict between Czechs and Germans.

The difficulty of ascertaining precisely how much national conflict Sabina and Smetana felt they were allowed to show in the opera is also illustrated in some of the textual passages that Smetana set in a musical sketch for the opera but excluded from the final libretto and the autograph score. ${ }^{40}$ Although some of these passages would have sharpened the perception of a national conflict in The Brandenburgers, others would have in fact undermined it. It is unclear, furthermore, whether Smetana decided to cut these passages because he feared the censors or for some other reason. Particularly significant for the changing concept of the national conflict are the cuts in Act III, Scene 7, in which the Czech people, represented by the chorus, search for Ludiše and her kidnapper Tausendmark. In one chorus that Smetana eventually cut, the people express their bloodthirsty anger at Tausendmark and call him a traitor of his country and nation: "We will go to all directions, / we will search for Ludiše, / we will punish the criminal [i.e., Tausendmark], / we will bathe in his blood. / The murderer has committed too many crimes, / he

\footnotetext{
${ }^{35}$ See also King, 26-27.

${ }^{36}$ On the distinction between historical and natural state rights, see Velké dějiny zemi Koruny české, vol. 12a, 83-89. The shifting focus of Czech nationalists in the 1860s is also discussed in Pieter M. Judson, The Habsburg Empire: A Nerw History (Cambridge, MA: Harvard University Press, 2016), 258-259, https://doi.org/10.4159/9780674969346, and Hugh LeCain Agnew, The Czechs and the Lands of the Bohemian Crown (Stanford, CA: Hoover Institution Press, 2004), 129.

${ }^{37}$ Očadlík, 42.

${ }^{38}$ Smaczny, 375.

${ }^{39}$ For a more extensive discussion of this phenomenon, see Martin Nedbal, "Sex, Politics, and Censorship in Mozart's Don Giovanni/Don Fuan," in The Oxford Handbook of Music Censorship, ed. Patricia Hall (New York: Oxford University Press, 2018), 175-202.

${ }^{40}$ On Smetana's sketches for the opera and the remnants of an original version of the libretto preserved in them, see Sabina, Braniboři v Čechách, xiv and 58-59.
} 
brandished his sword against the people, / he disgraced his fatherland and his nation, / he collaborated with foreigners." ${ }^{41}$ The excision of this section could be viewed as part of an effort to diminish the opera's representation of a national conflict. Yet, from the same scene Smetana also cut a passage in which Brandenburger Varneman talks to Junoš and the Czech chorus: "I spared your lives / although I could have killed you without fear / I have been observing you for a while / but I am not for whom you take me." ${ }^{22}$ Varneman here appears reasonable and less brutal than before, and the passage therefore suggests that Smetana initially operated with, but later rejected, a more sympathetic representation of the Brandenburgers.

A consideration of Austrian censorial procedures in the 1860s suggests, furthermore, that even a story depicting an open Czech-Brandenburger conflict would not necessarily have received harsh treatment from the censors. As Milan Pospíšil has shown, in the relatively liberal atmosphere of the 1860s, Austrian authorities loosened theatrical restrictions. Whereas, for example, during the absolutist and neoabsolutist periods of the 1830s and 1850s, French grand operas, such as Meyerbeer's Les Huguenots and Auber's Gustave III, were severely cut and altered prior to reaching the stages in Vienna and Prague, both the brief season of 1848 and the 1860s were periods of presenting these works without cuts and revisions induced by censorship. ${ }^{43}$ In the case of Les Huguenots, for example, the Czech and German productions in Prague were no longer required to shift the action from sixteenth-century Paris to thirteenth-century Pisa and avoid references to religious conflicts between the Catholics and the Protestants. Many operas, including Les Huguenots and Gustave III, moreover, were no longer required to diminish the gruesomeness of their violent endings and replace them with happy ones. Among the French operas imported to Prague and regularly performed in the early 1860s, Auber's La muette de Portici resembled The Brandenburgers in terms of the social and ethnic structure of its characters (the Neapolitans vs. the Spanish in La muette, the Czechs vs. the Brandenburgers in The Brandenburgers). Just as Les Huguenots and Gustave III, La muette had been heavily altered in its first Prague production of 1829: the poster for the premiere of the opera's German version, on July 30, 1829, suggests that the conflict between Neapolitans and Spaniards was suppressed; Alfonso, for example, is referred to as "Graf von Milone," not the son of the viceroy of Naples, and Elvira simply as his fiancée, not a Spanish princess. The posters for German performances show that this version of the opera remained on Prague's stages through the 1840s. ${ }^{44}$ The national and ethnic dimension of the conflict, however, reappears in the 1837 Czech production of the opera, as illustrated in the poster for the first Czech performance on January 8, 1837, which lists all the original characters and their national background. Clearly, in the Czech performances of the 1830s, national and social conflicts, even revolts, were not as sensitive a subject for Prague censors as attacks on royal figures.

One element that the Austrian authorities remained vigilant about, and that also might have affected The Brandenburgers, was religion and morality. This sensitivity affected Karel Šebor's opera Templári na Moravě (Templars in Moravia), set to a libretto by Sabina and premiered a few months before The Brandenburgers in the fall of 1865. As the protocol of the Prague censors from August 8, 1865 shows, the

\footnotetext{
${ }^{41}$ Sabina, Braniboři v Čechách, 60.

${ }^{42}$ Sabina, Braniboři v Čechách, 59.

${ }^{43}$ On Gustave III, see Milan Pospíšil, "Österreichische Opernzensur in Prag: Gustav III und La Fuive," in Eugene Scribe und das europäische Musiktheater, ed. Sebastian Werr (Berlin: Lit, 2007): 123-136; on Les Huguenots, see Milan Pospíšil, “Meyerbeerovi Hugenoti v Praze a rakouská cenzura: K 150. výročí skladatelova úmrtí,” Divadelní revue 25, no. 1 (2014): 3244.

${ }^{44}$ These posters are preserved in Prague, National Museum, Theater Department.
} 
only suggestion they had for Šebor's opera was that the nuns do not wear their official habits in Act II, Scene 3. ${ }^{45}$ The protocol also shows that on December 21, 1865, a censor read the libretto for The Brandenburgers and found no suspicious content. The smoothness with which The Brandenburgers passed the Prague censorial review is also documented in the censorial copy of the manuscript libretto preserved in the National Theater Archive. ${ }^{46}$ After the initial approval by the censor's office (marked in the protocol), the libretto also passed the review by the officials of the provincial government on December 29, 1865 (marked on the libretto's last page). Smetana's autograph, used as the conducting score during the Provisional Theater performances, together with the censorial libretto, used by the prompters, illustrates, however, that at some point either the censors or other theater supervisors became concerned about morals. ${ }^{47}$ Both the score and the libretto contain penciled-in revisions, executed during the Provisional Theater period (after the publication of the libretto's first edition in 1866), possibly even under Smetana's direction, in passages that are so awkward as to become sexually suggestive. ${ }^{48}$ One of the revisions (in Act III, Scene 4), for example, removes prominent double entendres from the conversation between Vlčenka and Ludiše, who worry about their safety in captivity:

\begin{tabular}{|c|c|c|c|}
\hline Original & & Revision & \\
\hline $\begin{array}{l}\text { Vlčenka } \\
\text { Ó bojím se každého } \\
\quad \text { okamžiku }\end{array}$ & $\begin{array}{l}\text { I am afraid of each single } \\
\text { moment, }\end{array}$ & $\begin{array}{c}\text { Bojím se ted' sama každé } \\
\text { chvíle. }\end{array}$ & I am afraid of each single \\
\hline $\begin{array}{l}\text { Aby nepřivolal nových } \\
\text { styků. }\end{array}$ & $\begin{array}{l}\text { Which can bring new } \\
\text { relations/intercourses }\end{array}$ & $\begin{array}{l}\text { Že nás zbaví kýženého } \\
\text { cíle }\end{array}$ & $\begin{array}{l}\text { Which can deprive me of } \\
\text { the desired goal. }\end{array}$ \\
\hline Děčana & & & \\
\hline $\begin{array}{l}\text { Pokud mezi neznámými } \\
\text { dlím, } \\
\text { Co se ještě stát může } \\
\text { nevím. }\end{array}$ & $\begin{array}{l}\text { As long as I am among } \\
\text { the strangers, } \\
\text { I don't know what can } \\
\text { happen. }\end{array}$ & $\begin{array}{l}\text { Pokud stále v cizích } \\
\text { dlíme rukou } \\
\text { Každý krok mi dál tím } \\
\text { větší mukou. } \\
\end{array}$ & $\begin{array}{l}\text { As long as we are at the } \\
\text { hands of others, } \\
\text { Each step is a torture for } \\
\text { me. }\end{array}$ \\
\hline
\end{tabular}

\section{Opera and Austrian-Czech Politics in the Early 1860s}

The early history of The Brandenburgers coincided with rapid and radical changes within Bohemian society, and this context further elucidates the confusing characterization of the opera's main figures. Smetana's decision to compose The Brandenburgers was initiated by Count Jan Harrach's patriotic decision to sponsor four prizes for new Czech historical and comic operas and librettos, first announced on February 10, 1861. A year later, Smetana received Karel Sabina's libretto, and by April 1863, he finished the musical setting. The opera was therefore created in the period immediately following the establishment of a limited parliamentary system by the February Patent of 1861 (see Table 1 for a chronological list of political and operatic developments in Bohemia in the 1860s). Czech politicians were figuring out how to advocate for the interests of Bohemia's population within the limited constitutional regime. After the regional election in Bohemia in March 1861, an alliance formed between representatives

\footnotetext{
${ }^{45}$ Prague City Archive, MHMP II./Divadelní referát NVP, kniha 17.

${ }^{46}$ Prague, National Theater Archive, Music Department, shelf mark H3, L8.

${ }^{47}$ The autograph score is in Prague, Bedřich Smetana Museum, shelf mark Tr I/2.

${ }^{48}$ Similar examples of censorial prudishness appear in other conducting and prompter's scores from nineteenth-century Prague theaters, such as in the Czech translation of Cosi fan tutte performed in the 1830s. See Martin Nedbal, "František Šír's First Czech Translation of Mozart's Final Opera Buffa and the Reception of Cosi fan tutte in Prague 1791-1831," Divadelní revue 27, no. 2 (2016), 67.
} 
of landed aristocracy, including Jan Harrach, the initial patron of The Brandenburgers, and members of the Czech National Party under the leadership of historian František Palacký and his son-in-law František Ladislav Rieger. The alliance sought to reverse the policies of centralization and Germanization pursued by the Austrian government in the 1850s. ${ }^{49}$ Throughout the 1860s, the alliance demanded that the Emperor and the Viennese leadership acknowledge what they referred to as "historical state rights," or the right of Bohemia, Moravia, and Silesia to form an autonomous unit within the Habsburg Empire because of their legacy as "the lands of the Bohemian crown." The idea of autonomy was kept strictly separate from the concept of independence, Bohemia was to remain part of a newly federalized Austria, and the Czech elites did not question the legitimacy of the Habsburgs as their rulers or of Vienna as the imperial capital. ${ }^{50}$ Prominent Czech politicians, especially Palacký in "The Idea of the Austrian State," subscribed to the notion that the Austrian Empire was in an ideal position to protect the small Slavic nations of Central Europe against their powerful neighbors to the West and East.

Table 1: Smetana's The Brandenburgers and Political and Operatic Events in Bohemia in the 1860s

\begin{tabular}{|c|c|}
\hline October 20,1860 & $\begin{array}{l}\text { October Diploma: a proclamation in which Emperor Franz Joseph promises to end } \\
\text { absolutism, institute an imperial parliament, and allow elections to regional diets. }\end{array}$ \\
\hline February 10, 1861 & $\begin{array}{l}\text { Count Harrach announces a competition for authors of original Czech comical and } \\
\text { historical operas. }\end{array}$ \\
\hline February 26,1861 & $\begin{array}{l}\text { February Patent: a constitutional document that establishes a two-chamber imperial } \\
\text { parliament in Vienna (one chamber appointed, the other elected) and sets rules for } \\
\text { elections to regional diets. }\end{array}$ \\
\hline March 1861 & $\begin{array}{l}\text { Regional elections to the Bohemian diet; the Bohemian regional parliament is divided } \\
\text { between Czech National Party, German Liberal Party, and the Party of the Land } \\
\text { Owners. }\end{array}$ \\
\hline November 18, 1862 & $\begin{array}{l}\text { The Provisional Theater, the first independent Czech theatrical institution, opens } \\
\text { with a performance of Cherubini's Les deux journées. }\end{array}$ \\
\hline April 23, 1863 & $\begin{array}{l}\text { Smetana finishes the composition of The Brandenburgers, according to a note in his } \\
\text { autograph score. }\end{array}$ \\
\hline October 19, 1865 & $\begin{array}{l}\text { The first original Czech historical opera Templári na Moravě (Templars in Moravia) } \\
\text { premieres at the Provisional Theater. }\end{array}$ \\
\hline January 5, 1866 & First performance of The Brandenburgers in the Provisional Theater. \\
\hline March 25, 1866 & $\begin{array}{l}\text { Smetana's The Brandenburgers is awarded the first prize from the Harrach competition } \\
\text { committee. }\end{array}$ \\
\hline May 30, 1866 & First performance of The Bartered Bride at the Provisional Theater. \\
\hline July 3, 1866 & Prussia defeats Austria in the Battle of Königgrätz/Hradec Králové. \\
\hline July 8,1866 & Prussian army occupies Prague; Smetana flees to the countryside. \\
\hline
\end{tabular}

\footnotetext{
${ }^{49}$ The Germanization of the 1850s is discussed in Velké dějiny zemi Koruny české, vol. 12a, 26-29.

${ }^{50}$ See Agnew, 146.
} 
Table 1 (cont.): Smetana's The Brandenburgers and Political and Operatic Events in Bohemia in the 1860s

\begin{tabular}{|l|l|}
\hline October 24, 1866 & $\begin{array}{l}\text { A performance of The Bartered Bride celebrating the visit to Prague of Emperor Franz } \\
\text { Joseph to express gratitude for support in the Austro-Prussian War. }\end{array}$ \\
June 8, 1867 & $\begin{array}{l}\text { Franz Joseph is crowned as Hungarian king in Budapest, which symbolically confirms } \\
\text { the separation of the Austrian Empire into a dual monarchy, consisting of a German- } \\
\text { dominated Cisleithania (including Bohemia) and a Hungarian-dominated } \\
\text { Transleithania. }\end{array}$ \\
May 16, 1868 & $\begin{array}{l}\text { The foundations of the National Theater in Prague are laid and Smetana's opera } \\
\text { Dalibor premieres. The ceremony turns into a Czech demonstration of disagreement } \\
\text { with the creation of the dual monarchy. }\end{array}$
\end{tabular}

The concept of Bohemia's ties to Austria operated in the works produced at the Provisional Theater, the first independent Czech theater constructed in 1862. Czech operatic productions at the Provisional Theater expressed the generally pro-Habsburg political sentiments that dominated the Czech political scene in the early 1860s. The very first opera in the Provisional Theater was Cherubini's Les deux journées (adapted as Vodař, based on the German adaptation Der Wasserträger), a work from Napoleonic France expressing generally liberal and humanistic (as opposed to nationalist) ideals easily associated with the new regime of constitutional Austria. On October 19, 1865, Šebor's Templări na Moravě (Templars in Moravia), premiered at the Provisional Theater and represented the first original Czech grand historical work produced by the relatively new opera ensemble. This work and its production were both an expression of the Czech calls for historical state rights and a proclamation of support for the Habsburg Emperor. The opera's opening was specifically made to coincide with the fifth anniversary of the October Diploma, the first constitutional law of the 1860s (issued on October 20, 1860). ${ }^{51}$ The opera connected with current political debates in that it featured collaborations between the royal court in Prague and Moravian aristocracy. An important aspect of the Czech demands for Bohemian autonomy in the 1860s was the reunification of Bohemian with Moravia and the Austrian Silesia, the historical lands of the Bohemian crown. According to the February Patent, however, the individual regional diets and governments of these three regional units were controlled directly by the central government in Vienna, which threatened to undermine their historical union. The opera's libretto plays with the idea of Bohemian-Moravian unity prominently. ${ }^{52}$ The main hero of the opera is the Moravian noble Vracen z Pernštýna who falls in love with a Bohemian noble woman, a member of the Prague court of an unspecified thirteenth-century Bohemian queen. The opera opens with a festive proclamation in which Bedřich z Cimburka, a Moravian noble (Cimburk is a castle in Southern Moravia), praises the Bohemian crown. As the Národní listy reviewer pointed out, during the premiere, this proclamation was met with tumultuous applause. The production and the anniversary celebration therefore combined an adulation of Emperor Franz Joseph as the bringer of constitutional liberties and the successor to the Czech throne with a subtle demand for an autonomous union of the lands of the Bohemian crown.

\footnotetext{
${ }^{51}$ The operatic celebration disregarded the fact that the Diploma was severely rewritten in the February Patent of 1861 ; the main difference was that whereas the Diploma afforded more autonomy to individual regions of the Empire, including Bohemia, the Patent was more centralistic. See Judson, The Habsburg Empire: A New History, 252-253.

${ }^{52}$ For an overview of political situation in Moravia in the early 1860s, see Velké dějiny zemi Koruny české, vol. 12a, 51-52. For a general overview of Moravian ties with Bohemia and Czechness, see Judson, The Habsburg Empire: A New History, 161. On the cooperation of Bohemian and Moravian Czech politicians in the Imperial Council in Vienna in the early 1860s, see Agnew, 129.
} 


\section{Dynastic Opera?}

Similar combination of pro-Habsburg sentiments and Czech patriotism can be associated with the choice of subject for Smetana's opera. Although the opera does not make it explicit, the history of the thirteenth-century Brandenburger occupation also involves Rudolph of Habsburg, the founder of the Habsburg dynasty's legacy in Central Europe. The Brandenburger rule in Bohemia was immediately preceded by the reign of Přemysl Otakar II, one of the most powerful late thirteenth-century rulers in Central Europe, who expanded his reign beyond the borders of the Bohemian kingdom, including into the Austrian lands in the south. His rise, however, was stopped by the arrival of Rudolph, who eventually defeated and killed Přemysl, and Přemysl's death led to the invasion of foreign mercenaries under the command of Přemysl's nephew Otto of Brandenburg. Ever since the thirteenth century, Bohemian and Czech chroniclers and historians viewed Rudolph of Habsburg as a force of stability in the uneasy transition period following Přemysl's death, a view that was still widespread among educated Czech subjects of Rudolph's successor, Emperor Franz Joseph I.

The main nineteenth-century works on thirteenth-century Bohemia that Sabina might have consulted were the second volume of Palacký's Geschichte von Böhmen, published (originally in German) in 1839, and again in 1847, and Tomek's 1855 Déjepis města Prahy (History of the city of Prague). ${ }^{53}$ Both historians are careful and conciliatory in their treatment of Bohemian-Habsburg relations during the Brandenburger period. ${ }^{4}$ Palackýs Geschichte, in fact, goes as far as to explicitly praise Rudolph as preferable to Otto of Brandenburg. In his discussion of the accord in which the two divided the rule of the kingdom (Rudolph becoming the Lord of Moravia, Otto of Bohemia) in late 1278, Palacký claims that "it is truly regrettable that the idea ... to give Rudolph the dominion over Bohemia did not succeed . . . [because his] power, cleverness, and righteousness would have rein in passions more efficiently and prevent attack from both sides [of the conflict]. ${ }^{" 55}$ Such historiographic viewpoints contradict in particular John Clapham's account of the opera's plot, according to which Otto was allegedly appointed as regent to "drive out the hated Hapsburgs." Conspicuously, when Palacký published the first Czech edition of the History's second volume in 1875, he cut the sentence celebrating Rudolf. ${ }^{57}$ This reflected the fact that by 1875, Czech-Habsburg relations were already strained (as explained below).

Brian Large points to the Chronicle of Dalimil as an important source for Sabina's treatment of the story in the libretto (the chronicle became widely known in Bohemia after it was published in 1786, and at the time of The Brandenburgers' inception it had been recently republished in 1853). ${ }^{58}$ Finished around 1315, the Chronicle might have been written by someone who experienced the events of the late $1200 \mathrm{~s}$ personally. Dalimil was notoriously anti-German, but this is partially the result of his support of the predominantly Czech-speaking Bohemian nobles. Because of this pro-nobility stance, moreover, Dalimil voices strong criticism not of Rudolph but of the authoritarian Přemysl and his decision to invite German

\footnotetext{
${ }^{53}$ Franz Palacký, Geschichte von Böhmen, vol. 2, part 1 ("Böhmen als erbliches Königreich unter den Přemysliden. Vom Jahre 1197 bis 1306”) (Prague: Kronberger und Weber, 1839); Tomek, Dějepis města Prahy; see also Karel Sabina, Braniboři v Čechách, ed. Zdeněk Nejedlý, xiv-xvi.

${ }^{54}$ In Tomek, see esp. pp. 188-203.

${ }^{55}$ Palacký, Geschichte von Böhmen, 327-328: "Darum ist es in Wahrheit zu bedauern, daß die Absicht der Königin Kunigunde, die Regierung in Böhmen dem Könige Rudolf zu überlassen, vereitelt wurde; des Königs Macht, Klugheit und Rechtlichkeit hätte die Leidenschaften besser gezügelt und die Übergriffe auf beiden Seiten gehindert.”

${ }^{56}$ John Clapham, Smetana (London: Dent and Sons, 1972), 90, https://doi.org/10.2307/955250.

${ }^{57}$ František Palacký, Dějiny národu českého w Čechách a w Moravě, vol. 2, part 1 (“Od roku 1253 do 1333”) (Prague: Tempský, 1875), 215.

${ }^{58}$ Large, 147.
} 
settlers and merchants to Bohemia. In a passage that Large mistakenly ascribed to Rudolph, Dalimil cites Přemysl's plan to stain Petřín Hill in Prague with Czech blood so that no Czechs will be left to walk across the Prague bridge. Dalimil also claims that the Bohemian nobles called on Rudolph to help them fight against Přemysl and his support of German settlement in Bohemia. ${ }^{59}$ In connection to the Brandenburger occupation, Dalimil blames the German city patriciate for helping the Brandenburgers and praises the nobles for bravely fighting them. Dalimil's account therefore sees Rudolph as a protector of the Czech-speaking community against German settlement. Similarly, the sixteenth-century chronicle by Václav Hájek z Libočan (widely read in the early nineteenth century) presents a celebratory portrayal of Rudolph, painting him as a magnanimous ruler who felt sorry for Bohemia after Přemysl's defeat and did not want to destroy the kingdom and outroot its people..$^{60}$

Pro-Habsburg sentiments also appear in the most important non-scholarly source of Sabina's libretto, Tyl's novella Braniboři v Čchách. Throughout the novella, Czech characters mourn the tragic death of Přemysl Otakar II, but blame treacherous Bohemian aristocracy for it, whereas Rudolph is depicted as an honorable ruler, who was supposedly moved when he saw Přemysl's dead body on the battlefield, shed tears, and covered it with his own coat. ${ }^{61}$ A powerful visual representation of Rudolph's magnanimity appears in Antonín Machek's enormously popular illustrated history of Bohemia, Děginy České $w$ kamenopisně wywedených obrazech (Czech history in lithographic pictures) (Figure 1). ${ }^{62}$ In Machek's lithograph of the battle on the Marchfeld, Rudolph rides a horse, wears a rich armor, and towers majestically over Přemysl's dead, naked body on the ground. Smetana must have known this illustration, since Machek was a childhood family friend, and Smetana's family treated a copy of the illustrated history as a prized possession. ${ }^{63}$ The hope that the Habsburg emperor Franz Joseph will be as magnanimous as his thirteenth-century predecessor and will confirm historical right on the lands of the Bohemian crown within a federalized Empire was particularly high in the period leading to the premiere of The Brandenburgers. On several occasions between 1861 and 1866, the emperor in fact acknowledged the autonomist demands from Bohemia and promised a coronation in Prague. Thus, a large portion of the enthusiastic crowds who attended the first performances of The Brandenburgers at the Provisional Theater between January and June 1866 firmly stood behind Austria in hopes of a federalist transformation.

\footnotetext{
${ }^{59}$ Dalimilova chronika česká, ed. Václav Hanka (Prague: Haas, 1853), 182.

${ }^{60}$ Václav Hájek z Libočan, Kronika česká, ed. Petr Voit (Prague: Academia, 2013), 606.

${ }^{61}$ Josef Kajetán Tyl, Braniboři v Čechách, in Sebrané spisy Josefa Kajetán Tyla, vol. 2, ed. František Sekanina (Prague: Kočí, 1908), 203.

${ }^{62}$ Děginy České w kamenopisně wywedených obrazech předstaweny od sgednocených umělcủ Akademie pražské, lithographic sheets by Antonín Machek (Prague: Bohmannských dědicové, [1820-1824]), 112; bi-lingual descriptions were published in Děginy České / Geschichte Böhmens, commentaries by Václav Hanka, vol. 3 (Prague: Sommer, 1824), 214-219.

${ }^{63}$ On Machek's relationship to Smetana and on the possible influence of the illustrated history on Libuše, see Zdeněk Nejedlý, Bedrich Smetana, vol. 2, Dětstoí (Prague: Orbis, 1950), 330-344.
} 


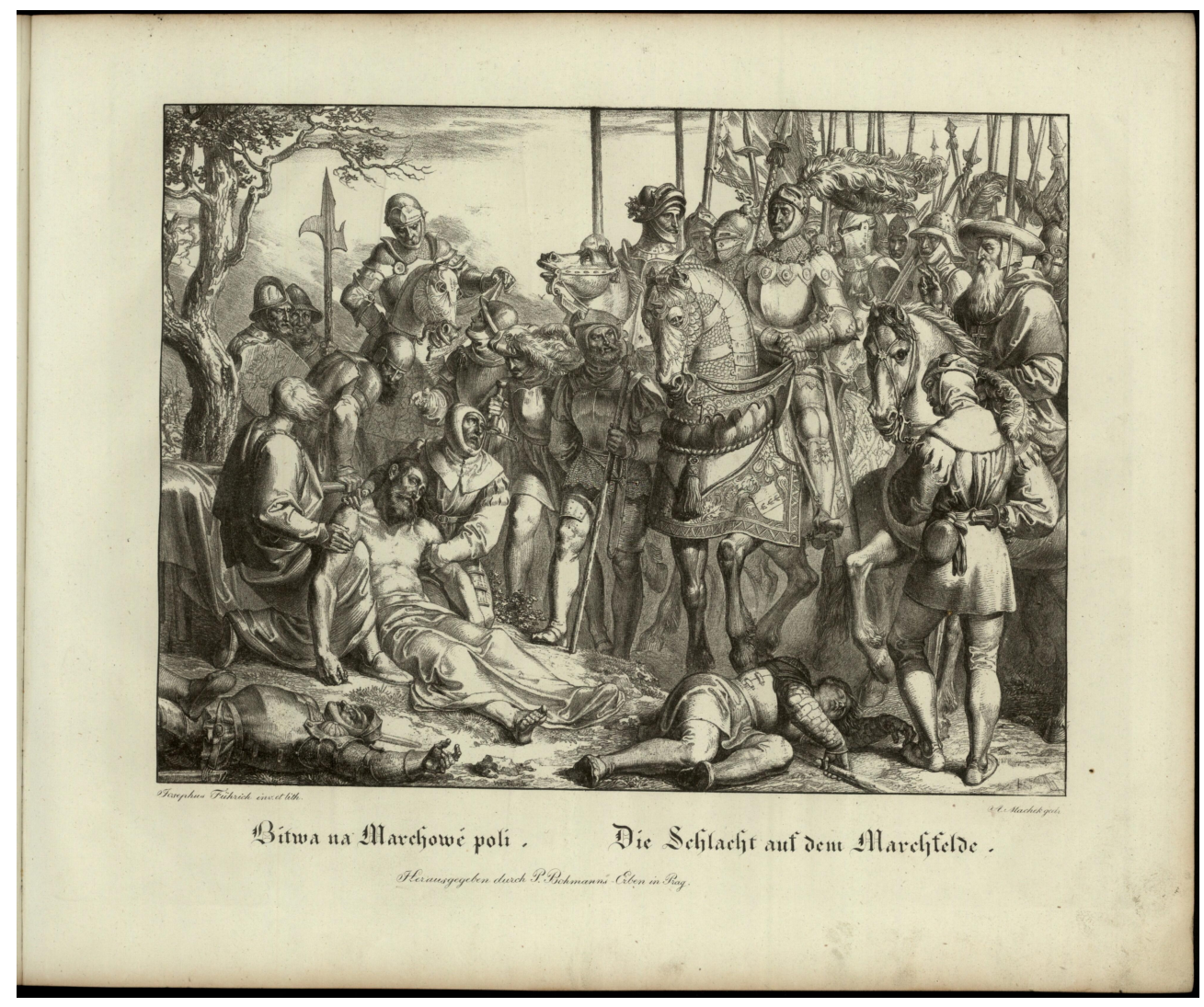

Figure 1: Antonín Machek's lithograph of the Battle on the Marchfeld (1278) in Dëginy České w kamenopisně wywedených obrazech (Czech history in lithographic pictures), 112.

\section{The Brandenburgers and the Austro-Prussian War}

It is easy to imagine, moreover, that some members of The Brandenburgers's first audience also experienced resentment toward Bismarck's Prussia. In early 1866 Prague newspapers were filled with news about increasing tensions between Austria and Prussia, which were to lead to the Austro-Prussian War that summer. Sabina and Smetana's reinterpretation of thirteenth-century history must have become a powerful symbol of the Bohemian distaste for the aggressive Prussian politics. This possibility is supported by the famous biographical episode, reported by pianist Josef Jiránek, in which Smetana, fearing repercussions against the author of The Brandenburgers, escaped from Prague for a period of five weeks as the Prussian army occupied the city after the destruction of the Austrian forces at the battle of Königgrätz/Hradec Králové. ${ }^{64}$ Similar understanding of the opera's symbolism might have guided Jan Neruda, who in one of his feuilletons in Národní listy (April 4, 1866), wrote that Prussians blamed the Austrian preparations for the war on the Czechs and supposedly cited Smetana's The Brandenburgers as a proof of the anti-Prussian feelings in Bohemia.

The political subtext of The Brandenburgers continued to draw attention even after the War concluded in August 1866. In the fall of 1866, Emperor Franz Joseph visited Prague to express his

${ }^{64}$ See Bartoš, Bedřich Smetana: Letters and Reminiscences, 103. See also St. Pierre, 53-54. 
gratitude to the loyal Bohemians during the War. As part of the visit, the Emperor attended both a performance in the German Theater (Gounod's Faust) and a performance of Smetana's The Bartered Bride in the Provisional Theater on October 24, 1866. Discussions in the contemporary press show that the opera initially planned to celebrate the Emperor's visit was The Brandenburgers, but the plan was changed likely out of concerns about possible protests from Germany. ${ }^{65}$ The initial choice of The Brandenburgers, for example, raised eyebrows in the German press-the Augsburg Allgemeine Zeitung (October 26, 1866) pointed out that the opera was filled with allusions to "recent events." This remark was noted in Vienna, since on November 19, 1866, the Wiener Zeitung (the official governmental paper in Austria) responded that the Allgemeine Zeitung author was reading too much into The Brandenburgers and the supposed allusions did not exist. This minor journalistic controversy shows that the opera was perceived as an important political symbol, and that this symbolism was pro-Austrian and anti-Prussian.

\section{Political Radicalism in The Brandenburgers}

The early reception of The Brandenburgers was also affected by political strife within Prague's Czech political circles. The Czech National Party became embroiled in conflict in 1863 when the Party's patriarchs Rieger and Palacký spoke against the anti-Russian January Uprising in Poland, and were criticized as henchmen of the tsars by members of the radical faction connected to Julius Grégr, the publisher of Národní listy, and to Count Rudolf Thurn-Taxis. Prague's German press soon started calling the radicals as "Jungčechen," Young Czechs, and the mainstream of the National Party was referred to as the Old Czechs. ${ }^{66}$ In their quest for more radical pursuit of autonomous rights for the Czechs, some members of the Young Czech platform in fact went as far as to promote the idea of an independent Czech state backed up by Prussia in the summer of $1866 .{ }^{67}$ Smetana is known to have associated with and found support among the radicals. ${ }^{68}$ Yet, in the summer of 1862, Smetana also hoped to become the music director of the Czech Theater, no matter how provisional it was, and his flight from Prague during the 1866 Prussian invasion of Bohemia shows that he was no supporter of the pro-Prussian faction within the radical circle. ${ }^{69}$

One aspect of The Brandenburgers, however, was viewed as radical already in the 1860s: the depiction of the Prague urban poor under the leadership of Jíra. One of the stipulations of Count Harrach's competition was that the music of serious operas should be based on "a thorough study of Czecho-Slavic national folk

\footnotetext{
${ }^{65}$ This plan to perform The Brandenburgers during the Emperor's visit was first announced in Národní listy, October 16, 1866. According to the Vienna Gemeinde-Zeitung (October 30, 1866), the reason why The Brandenburgers were replaced with The Bartered Bride had to do with new cast members in the opera production who required a longer period to learn the roles (The Brandenburgers was then performed only in late November). Several decades later, however, Hostinský pointed out that The Brandenburgers were rejected by Czech Theater intendant Rieger because they represented too close of a parallel "with the events of the recent past." Hostinský, 112.

${ }^{66}$ Velké dějiny zemi Koruny české, vol. 12a, 66.

${ }^{67}$ Velké dějiny zemi Koruny české, vol. 12a, 143-144.

${ }^{68}$ Velké dějiny zemi Koruny české, vol. 12a, 72. Smetana’s radical ideas about Czech culture in Prague in the early 1860s are also discussed in Jan Racek, Idea vlasti, národa a slávy v díle Bedřicha Smetany (Prague: Hudební matice Umělecké besedy, 1945), 68-70.

${ }^{69}$ On Smetana's attempts to become the musical director of the Provisional Theater in 1862, see Josef Bartoš, Prozatimni divadlo a jeho opera (Prague: Sbor pro zř́izení druhého Národního divadla, 1937), 15-16. Racek claims that Smetana was politically attuned to the Young Czech radicals already in 1863, but the quotes in which Smetana identifies himself as a Young Czech he provides are all only from the 1870s. See Racek, 70-72.
} 
songs" ("na pilném studiu prostonárodních nápěvů českoslovanských"). ${ }^{70}$ Smetana did not follow this requirement, creating a score that two of the competition judges, composer Johann Friedrich Kittl and pianist Sigmund Goldschmidt, viewed as full of references to Meyerbeer and Wagner. ${ }^{71}$ As one of the judges (Goldschmidt) pointed out, however, one exception within the generally cosmopolitan score of The Brandenburgers were scenes 7 and 8 of the first act. ${ }^{72}$ The music of these scenes is folk-like and includes a ballet emulating the Bohemian dances skočnáand polka with a brisk duple meter and ample syncopations (Ex. 2).

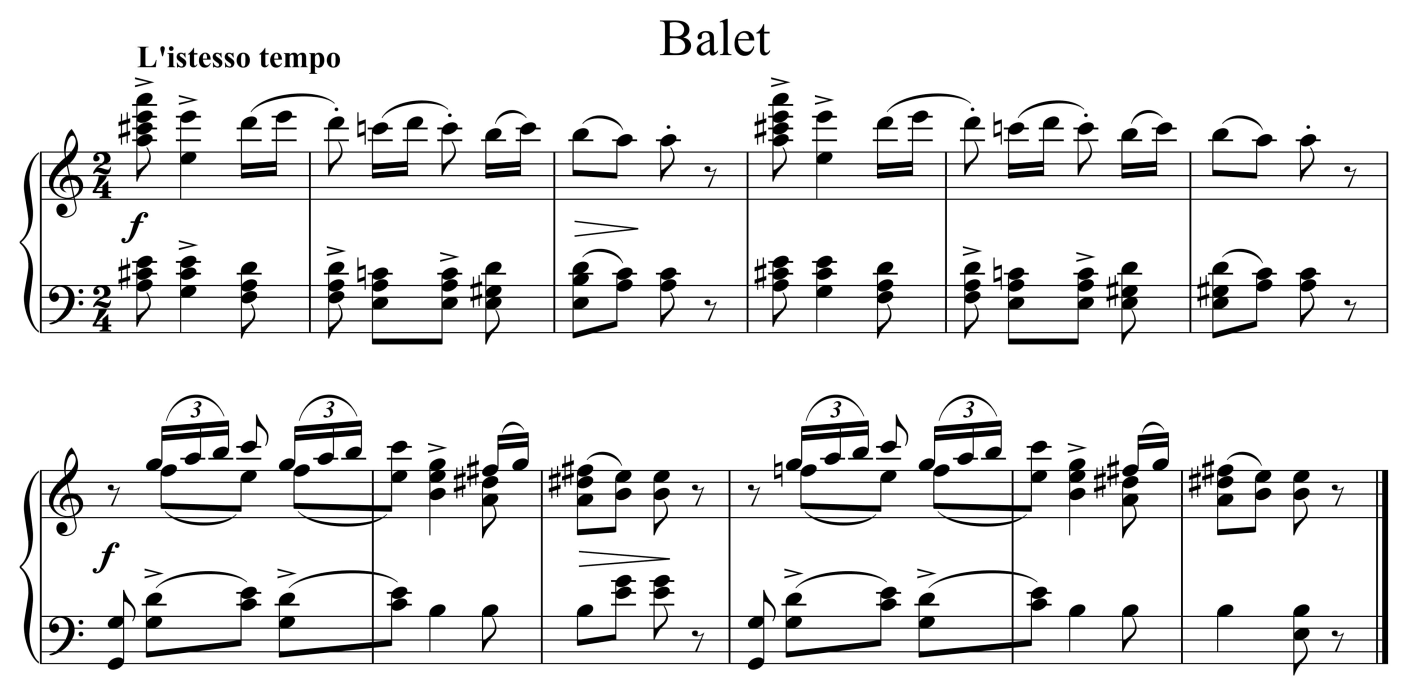

Example 2: Ballet of the Prague rabble in Act I, Scene 7, opening, mm. 282-293.

The Prague rabble's folk-like music is in fact much more in the style of "national folk songs" than the idioms associated with the peasants in the opening scenes of Act II, where the villagers fleeing the Brandenburgers first present a plea for divine protection in the style of an archaic, unaccompanied chorale (Act II, Scene 1, "Pane v prachu se kloníme"-Ex. 3) and then a rousing stretto in reaction to the news that the Brandenburgers have been ordered to leave the country within three days (Act II, Scene 3, "Slunko! Slunko!"-Ex. 4).

Yet, it was precisely these scenes that also became quite controversial. The two scenes depict the Prague urban poor as they loot the patrician houses under the leadership of Jíra, who also sings a choral aria ("Dobře chátro, dobře tak"). Jíra and his group are not at all patriotic and sing about revolting against the rich (Large's claim that the rabble is depicted as "fighting for freedom" might be related to post-WWII

\footnotetext{
${ }^{70}$ The competition proclamation is reprinted in V. H. Jarka, Kritické dílo Bedrícha Smetany (Prague: Nakladatelství pražské akciové tiskárny, [1948]), 320-321.

${ }^{71}$ Exact information about the judging of Harrach's competition was not clear until remnants of the judges' reports were discovered in the Harrach archive in Zámrsk in the 1970s. These reports were transcribed and published in Petr Daněk and Jana Vyšohlídová, "Dokumenty k operní soutěži o cenu hraběte Harracha,” Miscellanea musicologica 30 (Prague: Charles University, 1983), 147-176. See also Bohumír Smutný, "Dokumenty: Soutěž o Harrachovu cenu," Hudební věda 7, no. 2 (1970): 209-211; and Cyril J. Vejdělek, "Bejchorsko-kolébka naší zpěvohry i prvních pěvců,” Opus musicum 14, no. 9 (1982): 265-267.

${ }^{72}$ Daněk, 173.
} 
Marxist readings by Nejedlý, Očadlík, and others) ${ }^{73}$ Although the common people of Prague eventually join the Czech burghers' search for Volfram's daughters, abducted by the Brandenburgers, they do not display patriotic sentiments until the communal statement that concludes the opera. The opera's representation of the Prague mob is particularly prominent in comparison to Tyl's 1847 novella. The novella, too, focuses on the city poor, their destitute situation, their disregard for social order, and their proclivity toward violence. Unlike the opera, however, the novella on several occasions clearly connects the abject situation of the Prague mob to the Brandenburger rule of terror. At the end of the novella, furthermore, the mob joins Ctibor, a former courtier of Přemysl Otakar II, in a revolt against the Brandenburgers. No such patriotic revolt is depicted in the opera, where the Prague mob resembles brigands rather than revolutionaries. ${ }^{74}$
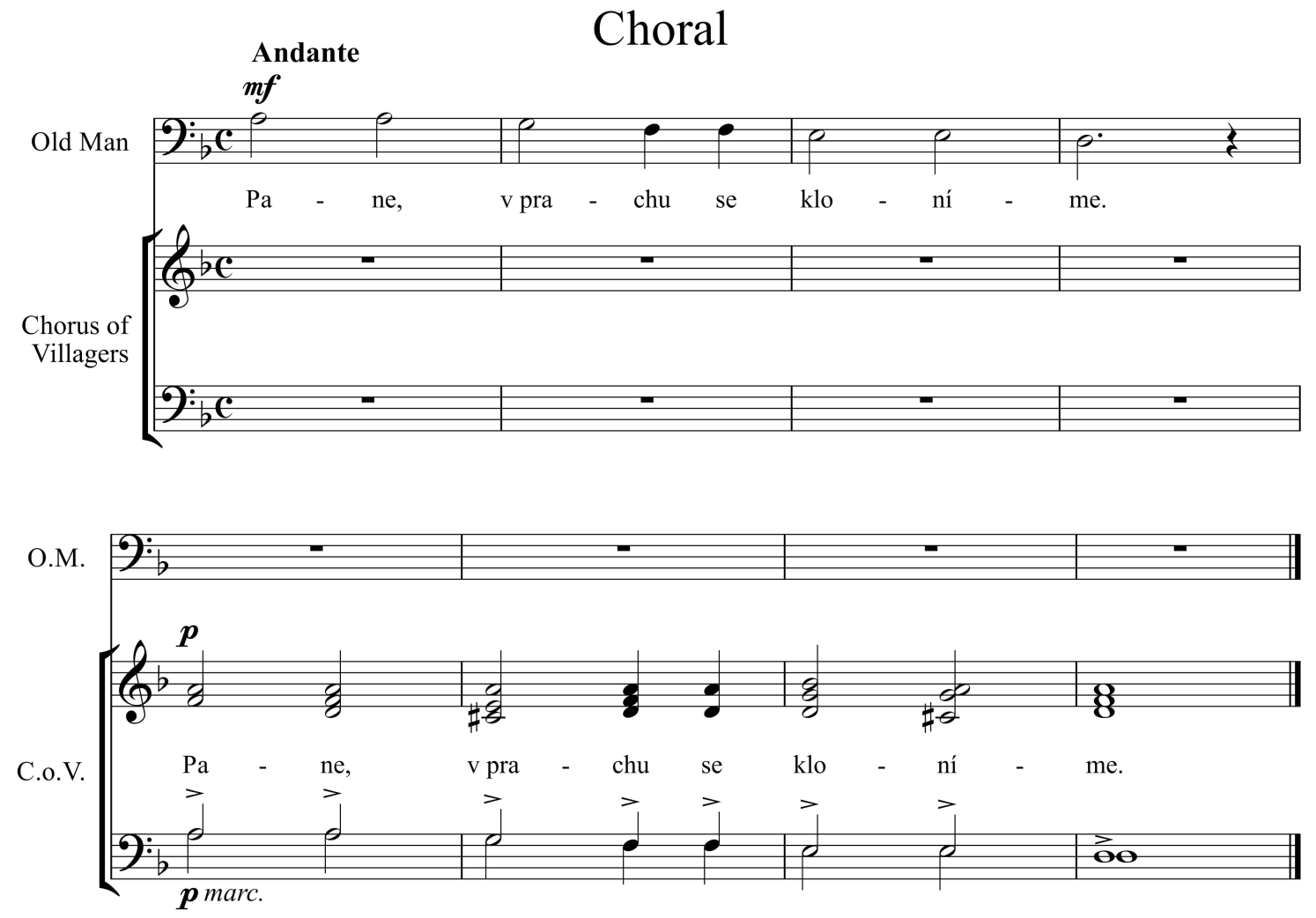

Example 3: Chorale of an old man and the chorus of villagers in Act II, Scene 1, opening, mm. 81-88. Text: "Pane, v prachu se kloníme. Pane, v prachu se kloníme." ("Lord, we bow down to the dust.")

\footnotetext{
${ }^{73}$ Large, 154. Očadlík, 16. Already in 1981, Marta Ottlová and Milan Pospíšil pointed out that the views of The Brandenburgers as "a revolutionary opera" because of the scenes with popular masses were based on superficial details. Marta Ottlová and Milan Pospíšil, “K problematice české historické opery 19. století,” Hudební rozhledy 34, no. 4 (1981): 170.

${ }^{74}$ See also Sabina, Branibořiv Čechách, xi.
} 

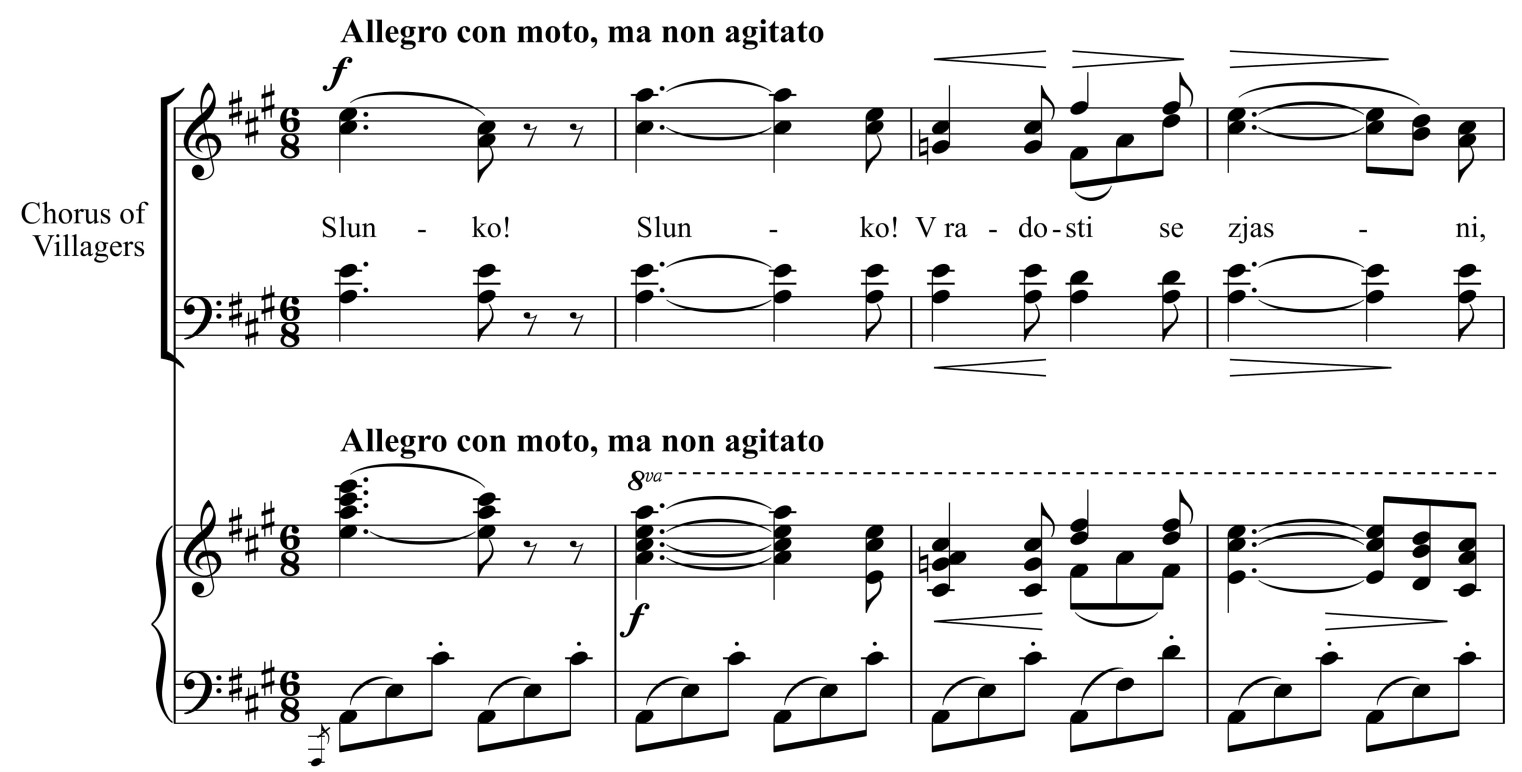

Ted.

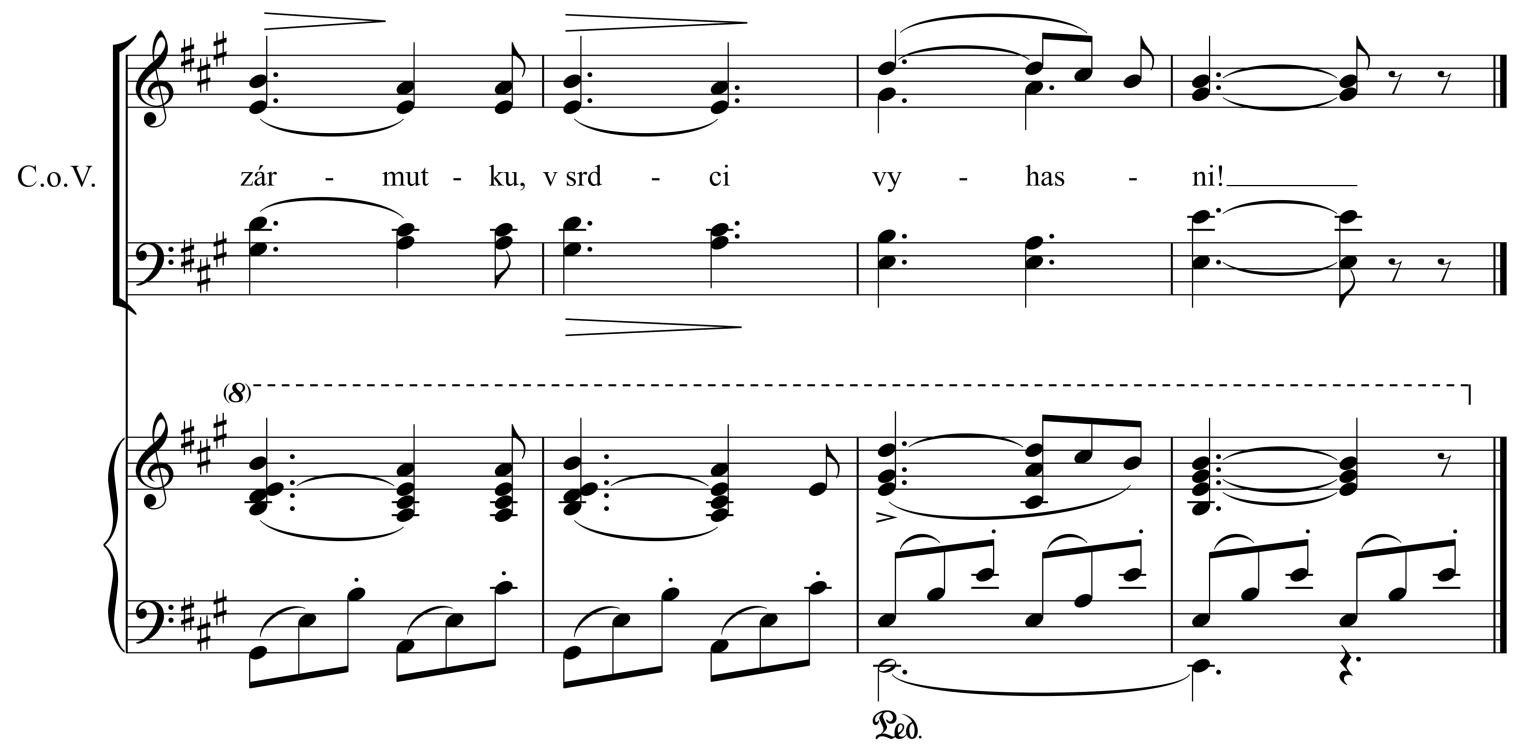

Example 4: Chorus of Czech villagers celebrates the news about the recall of the Brandenburger soldiers from Bohemia, Act II, Scene 3, opening, mm. 27-34. Text: "Slunko! Slunko! V radosti se zjasni, zármutku, v srdci vyhasni!" ("Sun! Sun! Shine brighter with joy, sadness, be extinguished in our hearts!")

In October 1864, Czech poet and folklorist Karel Jaromír Erben, who served on the committee of Count Harrach's libretto competition, complained that Act I, Scene 7 presents "a delightful company of communists of the most vulgar kind" ("rozkošnou společnost komunistů nejspros[t]šího způsobu"). ${ }^{75}$ The competition judge Goldschmidt thought Smetana's music for the mob scene was the most accomplished and folk-like part of the opera, but at the same time he feared that in combination with the libretto, the music "became too coarse" ("in eine zu niedrige Sphäre hinabgestiegen ist"). ${ }^{76}$ These views also appeared in critiques published in Prague newspapers after the premiere. The critic for Prague's main German

${ }^{75}$ Daněk, 153. On the ambiguity of Smetana's representation of the rabble, see also Tyrrell, 158-159.

${ }^{76}$ Daněk, 173. 
journal Bohemia (possibly August Wilhelm Ambros), for example, claimed that Jíra was the most interesting character of the whole opera, but his role was too episodic, and his connection to his native city and his compatriots was not marked by any "ennobling relationship" ("veredelndes Verhältniss"). ${ }^{77}$ Even Jan Ludevít Procházka, the critic of the most radically nationalistic Czech newspaper Národní listy, complains (on January 9, 1866) that although Jíra represents the character with the greatest depth in the opera, he does not "represent the idea of democracy in a flattering way" ("v němž se ostatně idea demokratická nerepresentuje př́liš lichotivě”).

Progressive Czech journalist Jan Neruda soon interpreted Smetana's association of the looting Prague rabble with the folk-like style as a reflection of the division in Czech political leadership. In a feuilleton in Národní listy published on January 14, 1866, Neruda mocked those members of the Czech theater directorship who were supposedly offended by the phrase "we are not rabble, we are the people" ("my nejsme luza, my jsme lid") that the mob sings in the first-act finale. ${ }^{78}$ Neruda might have been reacting to the statement in an earlier review of the opera in the conservative journal Politik (possibly written by Smetana's then-ally, František Pivoda), which claimed that the crowd scenes in Act I are effective but mainly represent "the ulcers of society" ("die Geschwüre der Gesellschaft"). In any case, Neruda's comment suggests that the opera's representation of the Prague rabble was particularly problematic for the more conservative and richer members of the Czech community (by then commonly referred to as the Old Czechs), including Rieger, the governmental supervisor of the Czech theater. The conservative elites would prefer national operas with choruses not of the common people but of large estate owners, Neruda adds mockingly. It is possible that Smetana's use of folk-like music in the rabble scene might be related to the, possibly apocryphal, story by Josef Srb-Debrnov about an argument Smetana had with Rieger as he was preparing to write The Brandenburgers. ${ }^{79}$ Rieger supposedly claimed that national opera should be based on folk songs, but Smetana called him ignorant and asserted that such an approach would result in a medley or a quodlibet, not an artistic work. ${ }^{80}$ If that argument did happen, then the rabble scene in The Brandenburgers might be considered Smetana's mocking musical response to the conservative Rieger: he associated the folk-like music the conservatives thought appropriate for a national opera not with idealized peasants (such as those in Weber's Der Freischütz, which was immensely popular among mid-nineteenth-century Czech audience) but with a naturalistic depiction of the urban poor.

\section{Czech National Movement in the late 1860s and The Brandenburgers}

One reason why it is tempting to read nationalistic meanings into The Brandenburgers is that the Czech national movement indeed started to radicalize in the late 1860s. This shift, however, received its main incentive, the Austro-Hungarian Ausgleich, only in 1867, one year after the initial production of The Brandenburgers in the Provisional Theater. The opera, furthermore, did not become a prominent cultural symbol of the changing political attitudes. The strong pro-Austrian sentiments among the Czech political elites were dealt a serious blow with the establishment of the dual Austro-Hungarian Empire in the spring

\footnotetext{
${ }^{77}$ Beilage zur Nr. 8 der Bohemia, January 10, 1866.

${ }^{78}$ St. Pierre relates Neruda's commentary specifically to his membership in Umělecká beseda, an organization founded in 1863 to promote Czech fine arts. She acknowledges its political content, but does not connect it to the factional divides within the National Party. St. Pierre, 51.

${ }^{79}$ See St. Pierre, $10-11$ and 49.

${ }^{80}$ The story is translated in Bartoš, Bedřich Smetana: Letters and Reminiscences, 67-68.
} 
of 1867. The reorganization of the Empire meant that Bohemia belonged to the German-dominated, Western part of the Empire, the so-called Cisleithania, and the calls for historical state rights were ignored. Czech political representatives considered these developments as ungrateful and treasonous and Czech commoners became more active in the national movement, participating in mass demonstrations in protest against Austrian policies. One such demonstration was the laying of the foundation for the (Czech) National Theater on May 16, 1868, which attracted large crowds. The shifting political interests of Czech elites and increasingly the larger public in Prague also came to the fore a few weeks later, when the public largely ignored the Emperor's visit of the Bohemian capital for the inauguration of Prague's third bridge across the Moldau/Vltava River. ${ }^{81}$ The situation eventually turned violent and a state of emergency was activated in Prague for several months in late 1868. Conspicuously, it is in 1868 that explicitly political, anti-German-Bohemian, and anti-Austrian statements also start appearing in Smetana's diaries: in January 1868, he complains that the new Cisleithanian government consists of "Germans only" ("samý Němec"), and in June 1869, when he returns from a visit to the newly built Vienna Court Opera, he notes: "The new theater is beautifully built, supposedly it cost 6 million. Vienna's money is only from our calluses." 82

Following the Austro-Prussian War, The Brandenburgers started to lose its initial political appeal. Smetana prepared a new production of the opera in the fall of 1866, after becoming the music director at the Provisional Theater (its premiere was initially envisioned to coincide with the Emperor's visit in late October, but eventually premiered only on November 28-for a list of the opera's productions at the Provisional and National Theaters, see Table 2). Despite a successful first performance that was praised by the press, the opera received only two performances in 1866 and was not brought back until October 18, 1867. At that time, some commentators came to understand The Brandenburgers as symbolic of the postAusgleich political situation. As both Národní listy and Politik point out (both on October 20, 1867), the second-act chorus of jubilation in which the persecuted Czech peasants welcome "freedom," elicited so much applause that it had to be repeated; the chorus might have touched on the frustration of many Czech audience members about the collapse of the historical state rights negotiations. At the same time, The Brandenburgers was withdrawn from the Provisional Theater's repertoire after three performances at the end of 1867. The opera was not performed at all during the tumultuous year of 1868. Another revival opened on November 26, 1869 and received four performances in late 1869 and early 1870, before disappearing from the Czech stage for seven years. ${ }^{83}$ Procházka's review in Národní listy (December 1, 1869) suggests that the work no longer resonated with the audience: whereas during the performances in 1866 and 1867, the choral scenes in the first and second act had excited the audience, in 1869 they were received calmly. Similarly, in an 1888 essay on Smetana's operas, Otakar Hostinský observed that although initially The Brandenburgers brought the audience to unprecedented excitement, in later times the opera met with coolness and indifference..$^{84}$

\footnotetext{
${ }^{81}$ Velké dějiny zemi Koruny české, vol. 12a, 195.

82 "Nové divadlo je nádherně stavěno, stálo prý 6 milionů. Vídeň má jen peníze z našich mozolů.” These diary entries are transcribed in Zdeněk Nejedlý, Smetaniana, vol. 1 (Prague: Melantrich, 1922), 150-151.

${ }^{83}$ These statistics are based on Václav Štěpán and Markéta Trávníčková, Prozatímni divadlo: 1862-1883, vol. 1 (Prague: Academia and Národní divadlo, 2006).

${ }^{84}$ Hostinský, 366. Hostinský also points out that whereas in the first year The Brandenburgers received thirteen performances, in the following 21 years, they were performed only eleven times.
} 
Table 2: Productions of The Brandenburgers in Prague, 1866-present

\section{Provisional Theater:}

\begin{tabular}{|c|c|c|c|}
\hline Date of premiere & $\begin{array}{l}\text { Conductor of } \\
\text { premiere }\end{array}$ & $\begin{array}{l}\text { Number of } \\
\text { performances } \\
\text { (Year of last } \\
\text { performance) }\end{array}$ & Notes \\
\hline January 5, 1866 & Bedřich Smetana & $12(1866)$ & $\begin{array}{l}\text { First production; last performance happened } \\
\text { the day before the outbreak of the Austro- } \\
\text { Prussian War }\end{array}$ \\
\hline November 11, 1866 & Bedřich Smetana & $5(1867)$ & $\begin{array}{l}\text { Was supposed to be premiered on the day of } \\
\text { Franz Joseph's visit to the Theater but was } \\
\text { postponed }\end{array}$ \\
\hline November 26, 1869 & Bedřich Smetana & $4(1870)$ & \\
\hline September 3, 1877 & Adolf Čech & $2(1877)$ & First production not conducted by Smetana \\
\hline September 28, 1880 & $\begin{array}{l}\text { Edmund } \\
\text { Chvalkovský }\end{array}$ & $4(1880)$ & \\
\hline
\end{tabular}

National Theater and the Fifth of May Theater (1945-1948)

\begin{tabular}{|c|c|c|c|}
\hline Date of premiere & $\begin{array}{l}\text { Conductor of } \\
\text { premiere }\end{array}$ & $\begin{array}{l}\text { Number of } \\
\text { performances } \\
\text { (Year of last } \\
\text { performance) }\end{array}$ & Notes \\
\hline April 9, 1885 & Adolf Čech & $2(1885)$ & Original version \\
\hline May 12,1888 & Adolf Čech & $2(1888)$ & $\begin{array}{l}\text { Commemorates the anniversary of Smetana's } \\
\text { death; original version }\end{array}$ \\
\hline January 7, 1893 & Mořic Anger & $3(1893)$ & Original version \\
\hline October 4, 1899 & Adolf Čech & $3(1900)$ & Original version \\
\hline May 12, 1903 & Karel Kovařovic & $10(1907)$ & $\begin{array}{l}\text { V. J. Novotnýs adaptation; commemorates } \\
\text { Smetana's death }\end{array}$ \\
\hline May 9, 1909 & Karel Kovařovic & $13(1915)$ & $\begin{array}{l}\text { V. J. Novotnýs adaptation; commemorates } \\
\text { 25th anniversary of Smetana's death }\end{array}$ \\
\hline May 12, 1916 & Karel Kovařovic & $15(1921)$ & V. J. Novotný's adaptation \\
\hline March 2, 1924 & Otakar Ostrčil & $26(1938)$ & $\begin{array}{l}\text { Original version; commemorates the } \\
\text { centennial of Smetana's birth; first post- } \\
\text { independence production }\end{array}$ \\
\hline
\end{tabular}


Table 2 (cont.): National Theater and the Fifth of May Theater (1945-1948)

\begin{tabular}{|c|c|c|c|}
\hline Date of premiere & $\begin{array}{l}\text { Conductor of } \\
\text { premiere }\end{array}$ & $\begin{array}{l}\text { Number of } \\
\text { performances } \\
\text { (Year of last } \\
\text { performance) }\end{array}$ & Notes \\
\hline September 4, 1945 & Václav Kašlík & NA (NA) & $\begin{array}{l}\text { First post-WWII production at the Fifth of } \\
\text { May Theater (formerly German Theater) }\end{array}$ \\
\hline September 9, 1945 & Otakar Jeremiáš & 17 (1948) & $\begin{array}{l}\text { Original version; first post-WWII production } \\
\text { at the National Theater; after the } \\
\text { Communist coup in 1948, replaced with the } \\
\text { production from the Fifth of May Theater }\end{array}$ \\
\hline May 8, 1952 & Jan Hus Tichý & $61(1959)$ & $\begin{array}{l}\text { Original version; first production under } \\
\text { Communism }\end{array}$ \\
\hline May 19, 1961 & Jan Hus Tichý & 47 (1968) & $\begin{array}{l}\text { Original version; last three performances in } \\
\text { the months following the Soviet-led } \\
\text { occupation }\end{array}$ \\
\hline May 14, 1984 & Zdeněk Košler & $36(1989)$ & $\begin{array}{l}\text { Original version; first production during the } \\
\text { post-occupation normalization }\end{array}$ \\
\hline November 15, 1997 & Bohumil Gregor & 15 (1999) & $\begin{array}{l}\text { Original version; first production after the } \\
\text { Velvet Revolution }\end{array}$ \\
\hline
\end{tabular}

\section{The Brandenburgers and Ethnic Nationalism}

In the late nineteenth century, The Brandenburgers gradually transformed into the iconic first opera of Czech music's founding father. ${ }^{85}$ After the new National Theater replaced the Provisional Theater in 1883, The Brandenburgers became one of its core repertoire pieces and was revived frequently, often to commemorate the anniversary of the composer's death on May 12 (see Table 2). During the same period, the Czech national movement radicalized and Czech-German relations grew more tense. The central Austrian government's politics of occasionally making small concessions to Czech demands and backing away from them due to German protests continued throughout the final decades of the Habsburg Empire. As a result, Czech elites gradually espoused more radically anti-German-Bohemian and anti-Austrian viewpoints. As Prague's Czech community embraced more radical forms of nationalism in the second half of the nineteenth century, German Bohemians gradually embraced new ideologies as well. As Judson explains, until the 1870s, German speakers throughout the Austrian Empire "tended to understand nation and its interests in terms of identification with their individual crownlands," but the political developments of the 1870s and 1880s "produced [a] more ethnic and cultural understanding of nationhood ... [and as a result] a new kind of German nationalism emerged in Bohemia, one that both reacted to and learned from its better-organized and more experienced Czech nationalist counterpart." ${ }^{" 86}$ Czech and German-Bohemian tensions further grew in the early twentieth century, as German-Bohemian

\footnotetext{
${ }^{85}$ On this process of glorification, see St. Pierre, chapters 2 and 3.

${ }^{86}$ Judson, The Habsburg Empire: A New History, 258 and 296-297.
} 
politicians managed to gain support from other German politicians in Cisleithania for the continual obstruction of Czech political demands from the central government in Vienna. ${ }^{87}$

The intensifying tensions between Czech and Bohemian German political elites are reflected in the revisions that were executed in the text and music of The Brandenburgers at the National Theater. The most radical of these revisions was undertaken by Václav Juda Novotný in connection to the 1903 production of The Brandenburgers, under the music direction of Karel Kovařovic. ${ }^{88}$ Novotný's adaptation introduced both smaller textual changes, large-scale reorganization, and additions of text and music. These transformations sharpen the antagonism between the Czech characters and their antagonists. Novotný also clearly associates the thirteenth-century Bohemian supporters of the Brandenburgers with modern German Bohemians. In Act I, Scene 2, m. 43, for example, Novotný and Kovařovic add the four-note statement "Němci zdejší" ("local Germans") to clarify the purported national identity of the local supporters of the plundering Brandenburgers. Even more prominently, Novotný and Kovařovic cut the section in Act III, Scene 1, where Varneman criticizes Tausendmark for betraying his own homeland. That statement is instead inserted into Act III, Scene 8 (the conducting score points out the transfer of $\mathrm{mm}$. 142-52 of Scene 1 to the penultimate scene in red pencil) and is assigned to Jíra, which creates a more radical differentiation between the Czechs and the German-Bohemian Tausendmark. Novotný also rewrites Jíra's final statement:

\begin{tabular}{|c|c|c|c|}
\hline $\begin{array}{l}\text { Sabina's } 1862 \\
\text { Original }\end{array}$ & & Novotný’s 1903 Revision & \\
\hline Nechte mne! & Let me be! & Nechte mne! & Let me be! \\
\hline $\begin{array}{l}\text { Domov můj jest šírý } \\
\text { svět, }\end{array}$ & $\begin{array}{l}\text { The whole world is my } \\
\text { home, }\end{array}$ & $\begin{array}{l}\text { Po vlasti takých } \\
\text { Tausendmarků }\end{array}$ & In [our] homeland, too many \\
\hline $\begin{array}{l}\text { Nepůjdu s vámi } \\
\text { zpět! }\end{array}$ & $\begin{array}{l}\text { I won't come back with } \\
\text { you! }\end{array}$ & Hojnost je. A já s oddanou & $\begin{array}{l}\text { Tausendmarks roam. And } \\
\text { with my }\end{array}$ \\
\hline $\begin{array}{l}\text { Cizincem jsem býval } \\
\text { vám, }\end{array}$ & $\begin{array}{l}\text { I used to be an alien to } \\
\text { you, }\end{array}$ & Svou chasou dál půjdu & Friends I will continue \\
\hline Ostanu povždy sám. & $\begin{array}{l}\text { I will always remain } \\
\text { alone. }\end{array}$ & $\begin{array}{l}\text { Proti vetřelcům ten drahý } \\
\quad \text { lid nášs } \\
\text { Věrně chránit chci! }\end{array}$ & $\begin{array}{l}\text { To faithfully protect our dear } \\
\text { people } \\
\text { Against these intruders! }\end{array}$ \\
\hline
\end{tabular}

In Sabina's original, Jíra reacts to the invitation from Junoš and Volfram's daughters to join and live with them in their home in Prague. The invitation, which Jíra eventually accepts by shaking Volfram's hand, represents an idealistic resolution of the social tension between the vagabond Jíra and the Prague patriciate. A chorus of the whole community concludes the opera celebrating the return of peace and the future glory of the homeland. Novotný's revision transforms Jíra's statement about social differences into a militantly nationalistic proclamation, in which Tausendmark and others like him, a veiled reference to other German Bohemians, are presented as intruders who need to be fought. Novotnýs revision was welcomed by the Národní listy critic (May 14, 1903), who now viewed Tausendmark simply as "a German ally" of the Brandenburgers.

Not all critics and commentators embraced Novotnýs adaptation of The Brandenburgers. Zdeněk Nejedlý criticized it in his 1936 book on the history of the National Theater opera, though not because of its nationalistic, anti-German transformation of Sabina's libretto, but because Novotný replaced Ludiše's

\footnotetext{
${ }^{87}$ Agnew, 146-150.

${ }^{88}$ Karel Sabina, Braniboři v Čechách, adapted by Václav Juda Novotný (Prague: Urbánek, 1904).
} 
two sisters with a younger brother and his nurse. ${ }^{89}$ When the opera was produced in 1924 under Otakar Ostrčil, who replaced Kovařovic as the director of opera at the National Theater in 1920 (with the support from Nejedlý), the original libretto by Sabina was restored. ${ }^{90}$ The original libretto was also used during 1945 production of The Brandenburgers at the Fifth of May Theater. Yet, the production brought another prominent nationalistic twist to the opera, as is clear not only from the staging with the swastika but also from the synopsis published in the program booklet. In the first-act rabble scene, for example, the original libretto shows the looters emerge from "a house," but in the program booklet they "take various items from houses of the Germans and the burghers who support them." The plot summary thus explicitly connects the opera with the mob rule in the streets of Prague during the tumultuous months after the end of WWII.

The 1945 production of The Brandenburgers in the former New German Theater was not only a powerful but also a strongly ironic symbol, because it reduced the centuries-long German-Bohemian existence in Prague to the six years of Nazi terror. In the 1930s, the New German Theater hosted numerous anti-Nazi émigrés from Germany and Austria. ${ }^{91}$ Many associates of the New German Theater during the First Czechoslovak Republic were German-Bohemian Jews who either emigrated once the Republic ceased to exist in 1938 or perished in later regimes. ${ }^{92}$ The Theater itself in fact ceased operations in early September 1938, a few days before the Munich Agreement between France, Great Britain, Germany, and Italy deprived the First Republic of its borderlands. ${ }^{93}$ Only during WWII was the New German Theater supervised by the Nazi authorities, acquired a large swastika decoration at the front entrance, and was used by visiting ensembles from the Reich.

\section{Anti-Occupation Opera?}

The widespread interpretation of The Brandenburgers as an allegory of a Czech national triumph over Austrian and German oppression relies on viewpoints that became relevant only decades after the opera's creation. Earlier commentators, including the two British Smetana biographers (Large and Clapham), might have also been influenced by post-WWII events. The status of The Brandenburgers as an anti-occupation opera was validated after the invasion of Czechoslovakia by the Warsaw pact armies in August 1968. Smetana's work lent itself all too easily to interpretations as a parable of the invasion and its aftermath: the continual presence of Soviet troops on the territory of Czechoslovakia. It is conspicuous that the opera was brought back to the National Theater three times in late September 1968 (though it had not been performed for two years before that), and then was withdrawn for most of the normalization

\footnotetext{
${ }^{89}$ Zdeněk Nejedlý, Opera Národního divadla od roku 1900 do převratu (Prague: Sbor pro zřízení druhého Národního divadla, 1936), 101. On Nejedlý's criticism of Kovařovic's leadership of the National Theater and of Novotnýs adaptations, see also Locke, 48-51. The transformation of the three sisters by Novotný had an anti-German dimension as well: the reviewer for Národní listy (May 14, 1903) points out that Sabina's three sisters were too much like "the three black ladies from Die Zauberflöte."

${ }^{90}$ On Ostrčil's early leadership of the National Theater, see Locke, 136-138 and 146-154. The 1924 production premiered on April 9, the centennial of Smetana's birth. The production's return to Sabina's original libretto was heavily contested in the press. See František Pala, Opera Národního divadla v obdobi Otakara Ostrčila, vol. 2 (Prague: Divadelní ústav, 1964), $283-285$.

${ }^{91}$ For an overview of the history of Prague's German theater in the 1930s and until 1945, see Jitka Ludvová, Až hořkému konci: Pražské německé divadlo, 1845-1945 (Prague: Academia, 2012), 496-518.

${ }^{92}$ Ludvová, 575 and 585-586.

${ }^{93}$ For a partially autobiographical overview of these developments, see Peter Demetz, Prague in Danger (New York: Farrar, Straus, and Giroux, 2008), 33-39.
} 
period (the next production did not occur until 1984)..$^{94}$

In his study of the ideological background of German musical monuments, Alexander Rehding points out that monumental music "has proved to be an extremely useful tool in the hands of totalitarian regimes" and that the popular aspects of national musical monuments can easily be abused for populism. ${ }^{95}$ The repeated interpretations of The Brandenburgers, a Czech musical monument, as anti-German and anti-Austrian is closely connected to such populist, totalitarian views; in fact, as the previous pages have shown, these views became particularly prominent during various totalitarian cataclysms in the midtwentieth century. It is time that Smetana's opera is embraced as a pluralistic, not totalitarian, work, a work that reflects the complex political and social conditions in mid-nineteenth-century Bohemia, and whose reception is tightly connected to various strains of Czech and Bohemian history. The Brandenburgers should be considered the first great Czech opera not primarily because of its glorification of ethnic Czechs but rather because of its fascinating mixture of often incongruous aspects and symbols associated with various fragmented and constantly evolving Czech and Bohemian identities.

\section{Bibliography}

\section{Archival Materials:}

Prague, Bedřich Smetana Museum

Smetana's notes in published annual calendars, 1862-1864, 1866-1883

Smetana's retrospective diary 1866-1875

The Brandenburgers sketches and autograph score

Prague City Archive

MHMP II./Divadelní referát NVP, kniha 17 (1863-1869)

Prague, National Museum, Theater Department

Theater poster collection

Prague, National Theater, Music Archive

The Brandenburgers, conducting scores, H3P

The Brandenburgers, censorial and directorial librettos H3L8-11

\section{Nineteenth-Century Newspapers:}

Augsburg Allgemeine Zeitung

Bohemia

Gemeinde-Zeitung

Národní listy

\footnotetext{
${ }^{94}$ See Andrew Clark, "Böhmisch-tschecho-slowakische Schicksaloper: Smetanas Die Brandenburger in Böhmen beim Prager Frühling," Opernwelt 25, no. 8-9 (1984): 90-91.

${ }_{95}$ Alexander Rehding, Music and Monumentality: Commemoration and Wonderment in Nineteenth-Century Germany (New York: Oxford University Press, 2009), 5, https://doi.org/10.1093/acprof:oso/9780195385380.001.0001.
} 
Politik

Wiener Zeitung

\section{Primary Literature:}

Dalimilova chronika česká. Edited by Václav Hanka. Prague: Haas, 1853.

Děginy České w kamenopisně wywedených obrazech předstaweny od sgednocených umělcu Akademie pražské. Prague: Bohmannských dědicové, [1820-1824].

Hájek z Libočan, Václav. Kronika česká. Edited by Petr Voit. Prague: Academia, 2013.

Hanka, Václav. Děginy České/ Geschichte Böhmens. Vol. 3. Prague: Sommer, 1824.

Palacký, František. Dějiny národu českého ${ }_{w}$ Čechách a w Moravě. Vol. 2, part 1 ("Od roku 1253 do 1333”). Prague: Tempský, 1875.

—. Geschichte von Böhmen. Vol. 2, part 1 ("Böhmen als erbliches Königreich unter den Přemysliden. Vom Jahre 1197 bis 1306”). Prague: Kronberger und Weber, 1839.

—. Idea státu rakouského. Prague, Kober, 1865.

Pečírka, Josef, and Emanuel Züngel. Švédové v Praze, composed by Jan Nepomuk Škroup. Prague: At the composer's expense, 1867.

Sabina, Karel. Braniboři v Čechách. Prague: Grégr, 1866.

—. Braniboři v Čechách. Prague: Urbánek, 1874.

—. Braniboři $v$ Čechách. Adapted by Václav Juda Novotný. Prague: Urbánek, 1904.

—. Braniboři $v$ Čechách. Edited by Zdeněk Nejedlý. Prague: Sbor pro postavení památníku Bedřichu Smetanovi, 1918.

—. Templäri na Moravě. Prague: 1865.

Štěpánek, Jan Nepomuk. Obležení Prahy od Švédů, aneb Vêrnost a udatnost Čechů. In Divadlo od J. N. Štěpánka, vol. 1, 3-124. Prague: Bohumil Ház, 1820.

Tomek, Václav Vladivoj. Dějepis města Prahy. Vol. 1. Prague: Řivnáč, 1855.

Tyl, Josef Kajetán. Braniboři v Čechách. In Sebrané spisy Josefa Kajetán Tyla, vol. 2, 285-326. Edited by František Sekanina. Prague: Kočí, 1908.

—. Měš̉ané a študenti. In Sebrané spisy Josefa Kajetán Tyla, vol. 3, 912-936. Edited by František Sekanina. Prague: Kočí, 1907.

\section{Secondary Literature:}

Agnew, Hugh LeCain. The Czechs and the Lands of the Bohemian Crown. Stanford, CA: Hoover Institution Press, 2004.

Bajer, Jiří, and Robert Smetana, eds. Dějiny české hudební kultury, 1890-1945. 2 vols. Prague: Academia, 1972-1981.

Bartoš, František. Bedřich Smetana: Letters and Reminiscences. Translated by Daphne Rusbridge. Prague: Artia, 1955.

Bartoš, Josef. Prozatimní divadlo a jeho opera. Prague: Sbor pro zřízení druhého Národního divadla, 1937. 
Borovička, Michael, Jiř́i Kaše, Jan P. Kučera, and Pavel Bělina. Velké dějiny zemí Koruny české. Vol. 12a. Prague: Paseka, 2012.

Brod, Max. Die verkaufte Braut: Das abendteuerliche Lebensroman des Textdichters Karel Sabina. Munich: Bechtle, 1962.

Brodbeck, David. Defining Deutschtum: Political Ideology, German Identity, and Music-Critical Discourse in Liberal Vienna. New York: Oxford University Press, 2014. https://doi.org/10.1093/acprof:oso/9780199362707.001.0001.

Campo-Bowen, Christopher. "An Operatic Locarno: The Paris Premiere of Smetana's The Bartered Bride and Czechoslovak-French Cultural Diplomacy." Cambridge Opera Journal28, no. 3 (2017): 282312. https://doi.org/10.1017/S0954586716000434.

Clapham, John. Smetana. London: Dent and Sons, 1972. https://doi.org/10.2307/955250.

Clark, Andrew. "Böhmisch-tschecho-slowakische Schicksaloper: Smetanas Die Brandenburger in Böhmen beim Prager Frühling." Opernwelt 25, no. 8-9 (1984): 90-91.

Cohen, Gary B. The Politics of Ethnic Survival: Germans in Prague, 1861-1914, second, revised edition. West Lafayette, IN: Purdue University Press, 2006.

Daněk, Petr and Jana Vyšohlídová. “Dokumenty k operní soutěži o cenu hraběte Harracha.” Miscellanea musicologica 30 (Prague: Charles University, 1983): 147-176.

Demetz, Peter. Prague in Black and Gold: Scenes from the Life of a European City. New York: Hill and Wang, 1997.

—. Prague in Danger. New York: Farrar, Straus, and Giroux, 2008.

Hostinský, Otakar. Bedřich Smetana a jeho boj za moderní českou hudbu. Prague: Leichter, 1901.

Jarka, V. H. Kritické dílo Bedřicha Smetany. Prague: Nakladatelství pražské akciové tiskárny, [1948].

Judson, Pieter M. Exclusive Revolutionaries: Liberal Politics, Social Experience, and National Identity in the Austrian Empire, 1848-1914. Ann Arbor: University of Michigan Press, 1996. https://doi.org/10.3998/mpub.15283.

—. The Habsburg Empire: A New History. Cambridge, MA: Harvard University Press, 2016. https://doi.org/10.4159/9780674969346.

King, Jeremy. Budweisers into Czechs and Germans: A Local History of Bohemian Politics, 1848-1948. Princeton, NJ: Princeton University Press, 2002. https://doi.org/10.1515/9780691186382.

Large, Brian. Smetana. New York: Praeger Publishers, 1970.

Locke, Brian. Opera and Ideology in Prague: Polemics and Practice at the National Theater, 1900-1938. Rochester, NY: University of Rochester Press, 2006.

Ludvová, Jitka. Až hořkému konci: Pražské německé divadlo, 1845-1945. Prague: Academia, 2012.

Mojžíšová, Olga. "Deníky Bedřicha Smetany. Jejich pramenná hodnota a ediční problematika." Ph.D. diss., Charles University in Prague, 2013.

Nedbal, Martin. "František Š́r's First Czech Translation of Mozart's Final Opera Buffa and the Reception of Così fan tutte in Prague 1791-1831,” Divadelní revue 27, no. 2 (2016): 53-70.

—. "Sex, Politics, and Censorship in Mozart's Don Giovanni/Don Juan." In The Oxford Handbook of Music Censorship, ed. Patricia Hall, 175-202. New York: Oxford University Press, 2018.

Nejedlý, Zdeněk. Bedřrich Smetana, vol. 2, Dětství. Prague: Orbis, 1950. 
Opera Národního divadla od roku 1900 do převratu. Prague: Sbor pro zřízení druhého Národního divadla, 1936.

—. Smetaniana, vol. 1. Prague: Melantrich, 1922.

—. Zpěvohry Smetanovy. Prague: Melantrich, 1949.

Očadlík, Mirko. Smetanovi Braniboři v Čechách. Prague: Orbis, 1953.

Ottlová, Marta and Milan Pospíšil. "K problematice české historické opery 19. století." Hudební rozhledy 34, no. 4 (1981): 169-172.

Pala, František. Opera Národního divadla v období Otakara Ostrčila, 4 vols. Prague: Divadelní ústav, 1962-1970.

Pospíšil, Milan. "Meyerbeerovi Hugenotiv Praze a rakouská cenzura: K 150. výročí skladatelova úmrtí.” Divadelní revue 25, no. 1 (2014): 32-44.

—. "Österreichische Opernzensur in Prag: Gustav III und La Juive." In Eugene Scribe und das europäische Musiktheater, ed. Sebastian Werr, 122-152. Berlin: Lit, 2007.

Pražák, Přemysl. Smetanovy zpěvohry, vol. 1. Prague: Vydavatelství za svobodu, 1948.

Racek, Jan. Idea vlasti, národa a slávy v díle Bedřicha Smetany. Prague: Hudební matice Umělecké besedy, 1945.

Rehding, Alexander. Music and Monumentality: Commemoration and Wonderment in NineteenthCentury Germany. New York: Oxford University Press, 2009. https://doi.org/10.1093/acprof:oso/9780195385380.001.0001.

Rychnovsky, Ernst. Smetana. Berlin: Deutsche Verlags-Anstalt, 1924.

Smaczny, Jan. "Grand opera among the Czechs." In The Cambridge Companion to Grand Opera, ed. David Charlton, 366-382. New York: Cambridge University Press, 2003. https://doi.org/10.1017/CCOL9780521641180.019.

Smutný, Bohumír. "Dokumenty: Soutěž o Harrachovu cenu.” Hudební věda 7, no. 2 (1970): 209-211.

St. Pierre, Kelly. Bedr̃ich Smetana: Myth, Music, and Propaganda. Rochester, NY: University of Rochester Press, 2017.

Štěpán, Václav and Markéta Trávníčková. Prozatímní divadlo: 1862-1883, vol. 1. Prague: Academia and Národní divadlo, 2006.

Taruskin, Richard. The Oxford History of Western Music. New York: Oxford University Press, 2010.

Teuber, Oscar. Geschichte des Prager Theaters, vol. 3. Prague: Haase, 1888.

Tyrrel, John. Czech Opera. New York: Cambridge University Press, 1988.

Vejdělek, Cyril J. “Bejchorsko-kolébka naší zpěvohry i prvních pěvců.” Opus musicum 14, no. 9 (1982): 265-267.

Vrbka, Tomáš. Státní opera Praha: Opera 1888-2003. Prague: Státní opera, 2004. 


\section{Acknowledgements}

Many thanks to Olga Mojžíšová (Bedřich Smetana Museum), and Aneta Peterová and Matěj Dočekal (National Theater Archive) for their help in exploring archival materials related to The Brandenburgers, to Peter Judson Kelley for setting the musical examples; to William Everett for providing an incentive for this article; and to the anonymous reviewers of this article for their insightful suggestions. 